Prepared for the U.S. Department of Energy

under Contract DE-AC05-76RL01830

\title{
Tc-99 Ion Exchange Resin Testing
}

MM Valenta

KE Parker

EM Pierce

August 2010

Pacific Northwest

NATIONAL LABORATORY

Proudly Operated by Battelle Since 1965 



\title{
DISCLAIMER
}

This report was prepared as an account of work sponsored by an agency of the United States Government. Neither the United States Government nor any agency thereof, nor Battelle Memorial Institute, nor any of their employees, makes any warranty, express or implied, or assumes any legal liability or responsibility for the accuracy, completeness, or usefulness of any information, apparatus, product, or process disclosed, or represents that its use would not infringe privately owned rights. Reference herein to any specific commercial product, process, or service by trade name, trademark, manufacturer, or otherwise does not necessarily constitute or imply its endorsement, recommendation, or favoring by the United States Government or any agency thereof, or Battelle Memorial Institute. The views and opinions of authors expressed herein do not necessarily state or reflect those of the United States Government or any agency thereof.

\author{
PACIFIC NORTHWEST NATIONAL LABORATORY \\ operated by \\ BATTELLE \\ for the \\ UNITED STATES DEPARTMENT OF ENERGY \\ under Contract DE-ACO5-76RL01830
}

Printed in the United States of America
Available to DOE and DOE contractors from the Office of Scientific and Technical Information,
P.O. Box 62, Oak Ridge, TN 37831-0062;
ph: (865) 576-8401
fax: (865) 5765728
email: reports@adonis.osti.gov

\author{
Available to the public from the National Technical Information Service, \\ U.S. Department of Commerce, 5285 Port Royal Rd., Springfield, VA 22161 \\ ph: (800) $553-6847$ \\ fax: (703) 605-6900 \\ email: orders@nits.fedworld.gov \\ online ordering: http://www.ntis.gov/ordering.htm
}





\title{
Tc-99 Ion Exchange Resin Testing
}

\author{
MM Valenta \\ KE Parker \\ EM Pierce
}

August 2010

Prepared for the U.S. Department of Energy under Contract DE-AC05-76RL01830

Pacific Northwest National Laboratory Richland, Washington 99352 



\section{Executive Summary}

The Hanford Site is a Federal facility in southeastern Washington State that manufactured nuclear materials for national defense between 1943 and 1988. In 1989, certain areas of the Hanford Site, including the 200-ZP-1 operable unit, were placed on the National Priorities List pursuant to the Comprehensive Environmental Response, Compensation, and Liability Act of 1980 (CERCLA).

Among the contaminants of concern in groundwater beneath $200-Z \mathrm{P}-1$ was technetium-99 $\left({ }^{99} \mathrm{Tc}\right)$, a radioisotope with a half-life of 210,000 years. Between April 26, 2007, and December 20, 2007, an ion exchange pilot-scale treatability test was performed to evaluate ${ }^{99} \mathrm{Tc}$ removal in a pump-and-treat system that would be installed as part of site cleanup. CH2M Hill Central Plateau Remediation Company (CHPRC) is responsible for the design and construction of the pump-and-treat system that will be installed at the Hanford site to support treatment of groundwater beneath 200-ZP-1. To support the largescale design of the system, two pilot-scale ion exchange columns were tested previously on groundwater collected from two different wells, one column per well. The column used to treat water from well 299W15-765 contained the highest ${ }^{99}$ Tc concentration as well as a nitrate concentration very similar to that expected in the influent of a full-scale treatment facility. The resin used to treat the groundwater in the pilot-scale test was Purolite A530E anion-exchange resin—-known for its relatively high anion selectivity. Purolite A530E is a monofunctional anion-exchange resin with triethylammonium exchange sites and the polystyrene backbone cross-linked with divinyl-benzene. This resin was chosen because there is a chemical bias toward exchanging $\mathrm{TcO}_{4}{ }^{-}$preferentially over the other anions in an aqueous solution.

Pacific Northwest National Laboratory was contracted by CHPRC to evaluate the release of ${ }^{99} \mathrm{Tc}$ from spent resin used to treat water from well 299-W15-765 and stored for several years. The key questions to be answered are as follows:

1) Does ${ }^{99}$ Tc readily release from the spent ion exchange resin after being in storage for several years?

2) If hot water stripping is used to remove the co-contaminant carbon tetrachloride, will ${ }^{99} \mathrm{Tc}$ that has been sequestered by the resin be released?

3) Can spent resin be encapsulated into a cementitious waste form? If so, how much ${ }^{99} \mathrm{Tc}$ would be released from the weathering of the monolith waste form?

The results from the long-term stability leach test results confirm that the resin is not releasing a significant amount of the sequestered ${ }^{99} \mathrm{Tc}$, which is evident by the less than $0.02 \%$ of the total ${ }^{99} \mathrm{Tc}$ loaded being identified in the solution. Furthermore, it is possible that the measured ${ }^{99}$ Tc concentration is the result of ${ }^{99}$ Tc contained in the pore spaces of the resin. In addition to these results, analyses conducted to examine the impact of hot water on the release of ${ }^{99}$ Tc suggest that only a small percentage of the total is being released. This suggest that hot water stripping to remove carbon tetrachloride will not have a significant effect on the resin's capability to hold-on to sequestered ${ }^{99}$ Tc. Finally, encapsulation of spent resin in a cementitious material may be a viable disposal option, but additional tests are needed to examine the extent of physical degradation caused by moisture loss and the effect this degradation process can have on the release of ${ }^{99} \mathrm{Tc}$. 



\section{Acknowledgements}

The authors wish to acknowledge Mark E. Byrnes and Sally A. Simmons at CH2M Hill Plateau Remediation Company (Richland, Washington) for providing project funding and technical guidance. The authors would also like to acknowledge the technical support of Jim Mavis from CH2M Hill Seattle Office. The authors also would like to thank S.R. Baum, E.T. Clayton, and I.V. Kutnyakov (all from PNNL) for helping carry out various aspects of the work described in this report. We are particularly grateful to Wayne Cosby (PNNL) for completing the editorial review of this technical report. 



\section{Acronyms and Abbreviations}

$\begin{array}{ll}\text { ANS } & \text { American Nuclear Society } \\ \text { ANSI } & \text { American National Standards Institute } \\ \text { CERCLA } & \text { Comprehensive Environmental Response, Compensation, and Liability Act of } \\ & 1980 \\ \text { CHPRC } & \text { CH2M Hill Plateau Remediation Company } \\ \text { DI } & \text { deionized (water) } \\ \text { DOE } & \text { U.S. Department of Energy } \\ \text { EDS } & \text { energy dispersive spectrometry } \\ \text { EPA } & \text { U.S. Environmental Protection Agency } \\ \text { EQL } & \text { estimated quantitation limit } \\ \text { HIC } & \text { high integrity container } \\ \text { IC } & \text { ion chromatography } \\ \text { ICP-MS } & \text { inductively coupled plasma mass spectroscopy } \\ \text { IDF } & \text { Integrated Disposal Facility } \\ \text { LI } & \text { Leachability Index } \\ \text { LLW } & \text { low-level waste } \\ \text { MDL } & \text { minimum detection limit } \\ \text { MS } & \text { mass spectroscopy } \\ \text { PDF } & \text { powder diffraction file } \\ \text { PH } & \text { measure of the acidity of a solution, where pH is the negative of the logarithm of } \\ \text { PNNL } & \text { the activity of H in solution } \\ \text { SEM } & \text { Pacific Northwest National Laboratory } \\ \text { XRD } & \text { scanning electron microscopy } \\ & \end{array}$





\section{Units of Measure}

$\theta$

$\AA$

${ }^{\circ} \mathrm{C}$

$\mathrm{cm}$

$\mathrm{pCi}$

g

$\mu$

$\mu \mathrm{m}$

$\mathrm{M}$

$\mathrm{mL}$

$\lambda$

wt $\%$ angle of incidence (Bragg angle)

angstrom $\left(10^{-10} \mathrm{~m}\right.$ or $\left.10^{-1} \mu \mathrm{m}\right)$

temperature in degrees Celsius $\left[\mathrm{T}\left({ }^{\circ} \mathrm{C}\right)=\mathrm{T}(\mathrm{K})-273.15\right]$

centimeter

picocuries

gram

micro (prefix, $10^{-6}$ )

micrometer

molarity, mol/L

milliliter

wavelength

weight percent 



\section{Contents}

Executive Summary ................................................................................................................

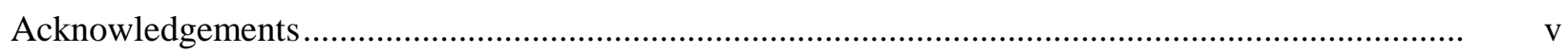

Acronyms and Abbreviations .......................................................................................................... vii

Units of Measure ................................................................................................................ ix

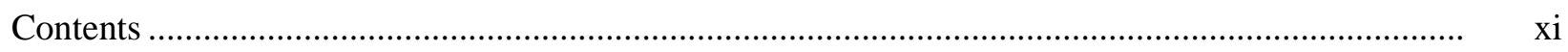

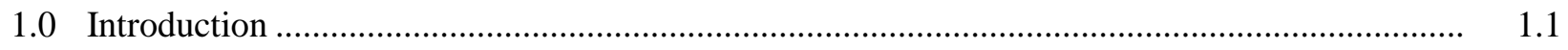

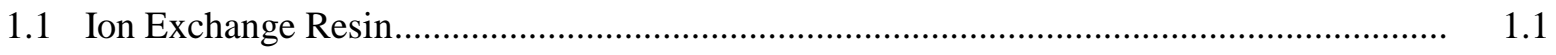

1.2 Overview-Review of Disposal Options for Spent Resins ............................................. 1.2

1.3 Review of Cement Solidification of Spent Resins ............................................................. 1.3

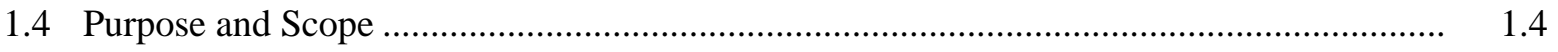

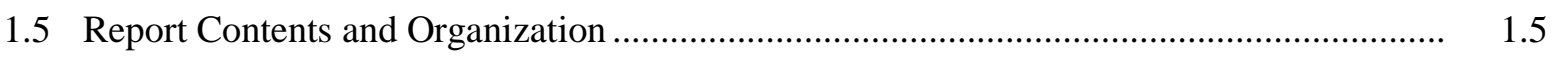

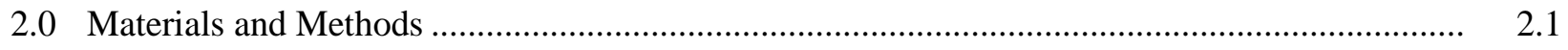

2.1 Sampling of the Ion Exchange Resin ........................................................................... 2.1

2.2 Ion Exchange Resin Moisture and Re-hydration .......................................................... 2.1

2.3 Long Term Stability ................................................................................................. 2.2

2.4 Stability in Heated Water ........................................................................................ 2.2

2.5 Resin Stabilization for Disposal ............................................................................. 2.3

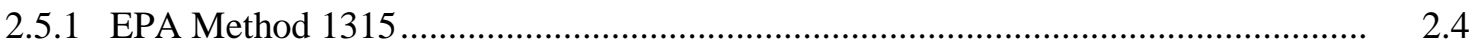

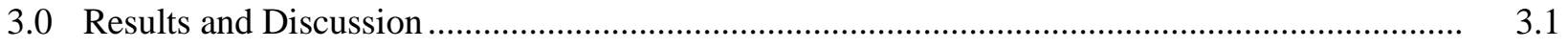

3.1 Ion Exchange Resin Moisture and Re-hydration ....................................................... 3.1

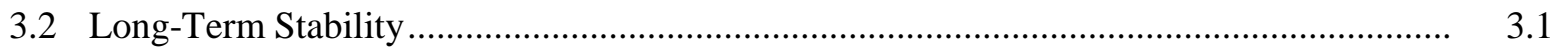

3.3 Stability in Heated Water ......................................................................................... 3.3

3.4 Resin Stabilization for Disposal .................................................................................

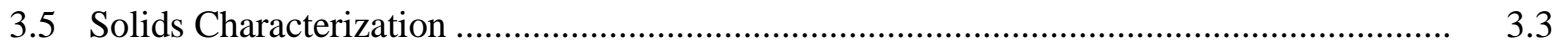

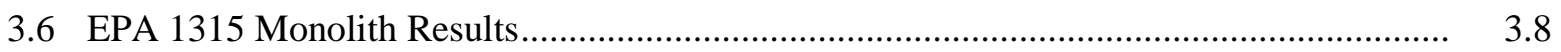

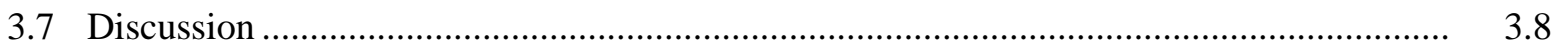

4.0 Conclusions and Recommendations ...................................................................................

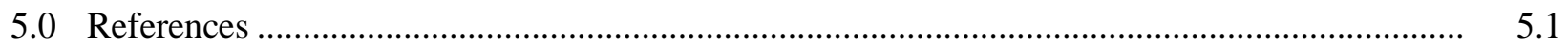

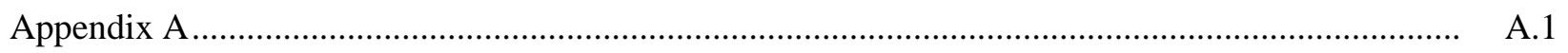

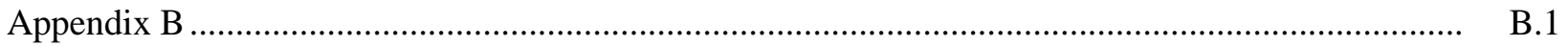





\section{Figures}

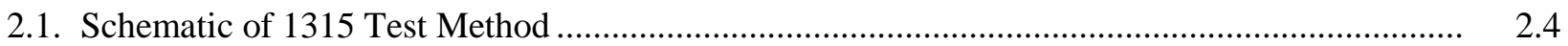

3.1. Results of the Long-Term Stability Leach Tests at Varying Solid-to-Solution Ratios................. 3.2

3.2. Results of the Additional Leach Test with Replacement of Deionized Water ............................ 3.2

3.3. Results of the Long-Term Stability Tests at Varying Temperatures ........................................... 3.3

3.4. X-Ray Diffraction Patterns for Raw Materials_Fly Ash (left) and Portland Cement

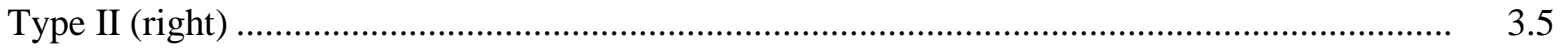

3.5. Fly Ash SEM Images and EDS Spectrum …..................................................................... 3.6

3.6. Portland Cement SEM Images and EDS Spectrum ................................................................

\section{Tables}

1.1. General Properties of Anion Exchange Resins ....................................................................... 1.2

1.2. Oxide Composition of ASC Specialty and Ordinary Portland Cements..................................... 1.4

2.1. Schedule for Long Term Stability Tests ............................................................................... 2.2

2.2. Schedule for Stability in Heated Water Test......................................................................... 2.3

2.3. Recipe Encapsulation Monoliths ............................................................................................ 2.4

2.4. Schedule for Resin Stability (Method 1315) Experiment .......................................................... 2.5

3.1. Moisture Content Results for the as-Received and Re-Hydrated Resin ................................... 3.1

3.2. Chemical Composition, in $\mu \mathrm{g} / \mathrm{g}$, of Raw Materials Used for Monolith Samples-Fly Ash

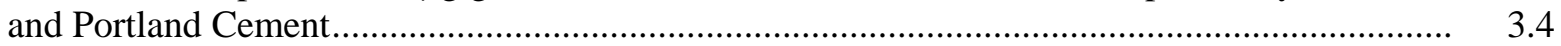

3.3. Average Diffusivity and LI Values for Encapsulated Spent Resin.......................................... 3.8

3.4. $\mathrm{K}_{\mathrm{d}}$ Results of the Long-Term Stability Leach Tests at Varying Solid to Solution Ratios ............ 3.9

3.5. $\mathrm{K}_{\mathrm{d}}$ Results of the Long-Term Stability Tests at Varying Temperatures ..................................... 3.9

3.6. $\mathrm{K}_{\mathrm{d}}$ Results from the Long-Term Stability Leach Test ........................................................... 3.10

3.7. $\mathrm{K}_{\mathrm{d}}$ Results of the Additional Leach Test with Replacement of Deionized Water ...................... 3.10 



\subsection{Introduction}

The Hanford site is a Federal facility in southeastern Washington State that manufactured nuclear materials for national defense between the years of 1943 and 1988. In 1989, certain areas of the Hanford Site, including the 200-ZP-1 operable unit, were placed on the National Priorities List pursuant to the Comprehensive Environmental Response, Compensation, and Liability Act of 1980 (CERCLA).

Among the contaminants of concern in groundwater beneath 200-ZP-1 was technetium-99 $\left({ }^{99} \mathrm{Tc}\right)$, a radioisotope with a half-life of 210,000 years. Between April 26, 2007, and December 20, 2007, an ion exchange pilot-scale treatability test was performed to evaluate ${ }^{99} \mathrm{Tc}$ removal in a pump-and-treat system that would be installed as part of site cleanup.

Two pilot-scale ion exchange columns were tested, each using groundwater from a different well. The pilot test column treating water from well 299-W15-765 contained the higher ${ }^{99}$ Tc concentration of the two wells as well as having a nitrate concentration very similar to that expected in influent to a fullscale treatment facility.

The ion exchange column that was tested with water from 299-W15-765 was stored for future examination and testing for purposes of waste characterization before disposal. The pending testing provides an opportunity to evaluate the stability of the ion exchange resin during long-term storage, to evaluate its ability to retain ${ }^{99}$ Tc during hot water stripping of carbon tetrachloride, and to assess its stability when grouted for disposal in a permanent, onsite waste disposal facility.

\subsection{Ion Exchange Resin}

Ion-exchange technology has been widely used for various separation processes, such as industrial processing of semi-conductors, water softening, and wastewater and groundwater treatment (Batista et al. 2000, Tripp and Clifford 2000, Helfferich 1995, Melis et al. 1996, Marina et al. 1996, Tao and Xiao 1996, Sorg et al. 1999, and Guseva et al. 1988). The ion-exchange mechanism is generally known as being the result of simple electrostatic interaction, although factors such as the size and nature of counter-ions, their hydration energy, and the types of functional groups on resin surfaces significantly impact the thermodynamics and kinetics of the exchange reactions (Moyer and Bonnesen 1997, Gu et al. 2000b, Brown et al. 2000). The optimal design and operation of an ion-exchange system thus require accurate knowledge of the thermodynamics and equilibria of the exchange reactions among various ions and counter ions in the system. Typical approaches for acquiring these data include measuring multicomponent ion exchange equilibria and developing thermodynamic models which, based on multicomponent equilibrium data, can predict multi-component exchange reactions. An overview of the various types of anion-exchange resins and their properties is provided in Table 1.1. 
Table 1.1. General Properties of Anion Exchange Resins

\begin{tabular}{cccc}
\hline Resin & Type & Amine Group & $\begin{array}{c}\mathrm{AEC}^{(\mathrm{a})} \\
\text { (mequiv/g) }\end{array}$ \\
\hline Purolite A530E & Polystyrene & $\left(\right.$ ethyl) ${ }_{3} \mathrm{~N} /\left(\right.$ hexyl) ${ }_{3} \mathrm{~N}$ & 2.2 \\
WBR109 & Polystyrene & $(\text { ethyl })_{3} \mathrm{~N} /\left(\right.$ butyl) ${ }_{3} \mathrm{~N}$ & 2.9 \\
Purolite A520E & Polystyrene & $\left(\right.$ ethyl) ${ }_{3} \mathrm{~N}$ & 2.8 \\
Purolite A500 & Polystyrene & $(\text { methyl) })_{3} \mathrm{~N}$ & 3.5 \\
Dowex 1-X8 & Polystyrene & (methyl) $)_{3} \mathrm{~N}$ & 3.2 \\
Purolite A850 & Polyacrylic, gel & (methyl) $)_{3} \mathrm{~N}$ & 3.9 \\
\hline
\end{tabular}

(a) AEC—anion-exchange capacity (dry weight equivalent).

In this report, we examine the stability of spent Purolite A530E anion-exchange resin-known for its relatively high anion selectivity - that was used in a pump-and-treat system to remove ${ }^{99} \mathrm{Tc}$ from contaminated groundwater at Hanford. Purolite A530E is a monofunctional anion-exchange resin with triethylammonium exchange sites and the polystyrene backbone cross-linked with divinyl-benzene. It was previously demonstrated that this material has the capability to remove significant amounts of perchlorate $\left(\mathrm{ClO}_{4}{ }^{-}\right)$and pertechnetate $\left(\mathrm{TcO}_{4}{ }^{-}\right)$from contaminated groundwater $(\mathrm{Gu}$ et al. 2000a, Bonnesen et al. 2000). In fact, Purolite A530E is currently being used to remove $\mathrm{TcO}_{4}{ }^{-}$from the contaminated groundwater at the U.S. Department of Energy’s Paducah Gaseous Diffusion Plant site in Kevil, Kentucky (Gu et al. 2000b). Because $\mathrm{TcO}_{4}{ }^{-}$is larger and has a lower hydration energy than most of the other anions encountered in groundwater (such as $\mathrm{Cl}^{-}, \mathrm{HCO}_{3}{ }^{-}, \mathrm{SO}_{4}{ }^{2-}, \mathrm{NO}_{3}{ }^{-}$), there is a chemical bias toward exchanging $\mathrm{TcO}_{4}{ }^{-}$preferentially over the other anions in an aqueous solution (Gregor et al. 1955). This bias can be enhanced by chemical modification of the resin, including altering the size and shape of the cationic exchange sites and the polymer cross-linking density. It was found that resin selectivity for $\mathrm{TcO}_{4}{ }^{-}$sorption increased with the radius of the immobilized alkyl chain length of the quaternary ammonium groups on resin beads; however, the increase in radius also resulted in an overall decrease in the exchange capacity and rate of anion exchange (Bonnesen et al. 2000).

\subsection{Overview-Review of Disposal Options for Spent Resins}

A review of the current practices for ultimate disposal of spent organic-based resins yielded several observations. Although cement solidification of spent ion-exchange resins is still being considered or actively practiced in countries such as China, Serbia, and Turkey, currently spent resins at U.S. commercial low-level waste (LLW) burial grounds are disposed of (after dewatering) in either steel containers for Class A wastes or in high-density polyethylene high-integrity containers (HICs) for Class C wastes. The following synopsis was obtained in telephone conversations with an environmental health physicist at one of the few commercial LLW burial grounds in operation within the United States. ${ }^{(a)}$ The Class C dewatered spent resins within HICs are placed within concrete boxes to provide structural support

(a) This information was obtained during two phone conversations with Bob Haight, Environmental Health Physicist with U.S. Ecology Washington, Inc., Richland, Washington, in August 2009. 
after burial. Most states that regulate commercial LLW burial grounds do not allow any credit for the integrity of the steel containers once they are buried in the subsurface sediments. Hence, only Class A designated dewatered spent resin wastes can be transported and disposed of in the steel containers. State regulators give the concrete boxes a lifetime of at least 1000 years and also assume that the high-density polyethylene HICs provide additional containment. The concern with the HICs is that they cannot take the overburden pressures of the sediment that is used to backfill the trenches. Thus, the HICs are overpacked with the concrete boxes to provide the rigidity needed to keep the overburden compressive forces from crushing the HICs. Herbst (2002) also concluded that the best option for disposing of spent ion-exchange resins generated as a secondary waste stream from vitrification of sodium-bearing waste from the Idaho Nuclear Technology and Engineering Center was dewatering, placement in HICs, and disposal in shallow-land burial facilities. A current draft report that collates the types and quantities of secondary wastes that are to be produced at the Hanford Tank Waste Treatment and Immobilization Plant (WTP) suggests that the spent resorcinol-formaldehyde resins are to be placed in HICs and, because of the high dose rates, need to be remotely handled during transit and burial in the Integrated Disposal Facility (IDF) (see Gehner et al. 2009). There is no mention whether the HICs are to be high-density polyethylene or some other material. If high-density polyethylene HICs are used, placing the HICs in concrete overpacks as is done for Class C commercial waste would be advised.

\subsection{Review of Cement Solidification of Spent Resins}

In the past, spent resins often were solidified into cement waste forms, but several problems have caused this solidification process to be mostly abandoned, at least in the United States. The benefits for solidification of spent ion-exchange resins in cement include the use of simple equipment and ease of scale-up. Low temperatures are adequate for solidification, the final products are relatively resistant to physical deformation from overburden pressures after burial or during transport to the burial ground, and the costs are relatively low. A major drawback to solidification of spent resins into cement is the loading limitations, which are in the range of $20 \%$ wet resins, to the dry blend of solidification agents. For example, an optimum recipe used in China in the 1990s (Pan et al. 2001) to solidify spent resins was blast furnace slag (BFS) $24 \mathrm{wt} \%$, fly ash $24 \mathrm{wt} \%$, OPC $8 \mathrm{wt} \%$, $24 \mathrm{wt} \%$ of spent resin, and $20 \mathrm{wt} \%$ water. These limitations are necessary to prevent swelling and cracking of the product after or during short-term curing (Li and Wang 2006).

Compared to many liquid and solid radionuclide-bearing wastes, spent ion-exchange resins are more difficult to solidify. Ion-exchange beads that are not already saturated with water swell when contacted with water, generating internal pressures that can reach $50 \mathrm{MPa}$. Even when water-saturated resins are used, if the ratio of resin to other ingredients rises much above $25 \%$, swelling and cracking is generally observed. The most likely cause is that the resins and hydrating cement phases compete with each other for free water. Neilson and Columbo (1982) found that cement solidification of ion-exchange resins, especially large cement right-cylinder monoliths, deteriorated after several weeks when monoliths were leached in water. Hairline cracks developed and then widened with time. The authors hypothesized that heat generated during cement hydration built up internally and drove water out of the resins, which caused swelling pressures in the larger specimens. Sperazini and Buckley (1981) recommended that spent organic exchange resins first be incinerated to form ash before solidification into cement to avoid swelling and cracking. They found that incineration of resins to ash improved ${ }^{137} \mathrm{Cs}$ leach resistance of the final cement product by over a factor of 10 . 
In China, a new type of cement, ASC, with higher aluminum and sulfur oxide content, less silicon and calcium oxides (see Table 1.2), and a mixture of zeolites has been found to be superior for encapsulating spent ion-exchange resins ( $\mathrm{Li}$ et al. 2005). Li et al. (2005) recommend a recipe of 35-wt\% ASC cement, 7 -wt\% zeolite, $42-w t \%$ spent resins (that have a gravimetric moisture content of 50\%, i.e., close to saturated), and 16 -wt\% water. The zeolite helps in sequestering radionuclides (e.g., ${ }^{137} \mathrm{Cs}$ and ${ }^{60} \mathrm{Co}$ ) that desorb from the spent resins during the cement hydration reactions that generate high-ionic-strength pore waters.

Table 1.2. Oxide Composition of ASC Specialty and Ordinary Portland Cements

\begin{tabular}{lcc}
\hline Oxide & \multicolumn{2}{c}{ ASC } \\
(wt\%)
\end{tabular}

The spent ion-exchange resins do not interact with the crystalline and amorphous gel minerals that form upon cement hydration; rather, they are simply physically encapsulated within the cement or grout solids ( $\mathrm{Li}$ and Wang 2006). The diffusion of constituents from a cement or grout that solely physically encapsulates waste can be reduced by decreasing the pore sizes, pore throat sizes, and pore connectivity (i.e., increased tortuosity) in the cement matrix. The porosity can be altered by varying the types of solid oxides and minerals and their amounts used in the dry blend. However, lowering the porosity of the hardened product by changing the dry blend generally leads to lowered compressive strength of the hardened cement. Although encapsulation in a cementitious material is not the current practice at the one LLW facility in the US, evaluation of this option is needed to support a disposal decision that will be needed for any of the Hanford sites LLW facilities (e.g., ERDF and/or IDF).

\subsection{Purpose and Scope}

The purpose of Pacific Northwest National Laboratory's (PNNL's) work documented in this report is to conduct an evaluation of ${ }^{99} \mathrm{Tc}$ release from spent ion exchange resin. This document describes the results collected as part of an analysis of spent resin stability and stabilization for disposal. As part of the pilot scale treatability test, CH2M Hill Plateau Remediation Company (CHPRC) has contracted PNNL to 
conduct experiments on the Purolite A530E ion exchange resin used to treat groundwater from well 299W15-765.

\subsection{Report Contents and Organization}

The ensuing sections of this report document the materials and steps used to sample, rehydrate, and determine the moisture content of the as-received and rehydrated spent resin (Section 2.0). The materials and steps used to evaluate ${ }^{99}$ Tc release from the spent resin after aging, after being exposed to heated water, and after being stabilized in a cement-based waste form. The results collected from these methods are presented, discussed, and summarized in Sections 3.0. The conclusions and recommendations are provided in Sections 4.0. 



\subsection{Materials and Methods}

\subsection{Sampling of the Ion Exchange Resin}

Approximately 2 liters of ion exchange resin sampled from the top of the ion exchange column was shipped to PNNL from CHPRC. Because the pilot tests were conducted in a down-flow mode, CHPRC removed aliquots of resin from the top of the column because it was expected to contain the highest concentration of ${ }^{99} \mathrm{Tc}$. After being sampled, these materials were packaged and shipped to PNNL.

\subsection{Ion Exchange Resin Moisture and Re-hydration}

Due to long-term storage of the spent ion exchange columns, re-hydration of the resin was conducted before performing experiments. Before re-hydrating, a subsample ( $10 \mathrm{~g})$ of the as received resin was collected to analyze for the moisture content. To re-hydrate the resin, the resin was placed in a vacuum and a $1000 \mathrm{mg} / \mathrm{L} \mathrm{NaCl}$ solution was introduced to the resin. The resin and $\mathrm{NaCl}$ solution were kept under vacuum over night to verify that the resin was completely saturated by the $\mathrm{NaCl}$ solution. Once complete, the vacuum was slowly released to allow the resin to pull the saline solution into the beads. A subsample of the solution from this process was analyzed for ${ }^{99}$ Tc and other major and minor cations.

Approximately 400 to 500 grams of resin was rehydrated for subsequent experiments.

The moisture content of the as received and hydrated ion exchange resin was determined. The moisture content measurement allows for the amount of water contained in the resin to be subtracted from the total mass of sample used. Determining the concentration of ${ }^{99}$ Tc per gram of dry resin allows for the rate of release to be corrected based upon the loading. To obtain residual moisture content, approximately 10 grams of ion exchange resin was placed into a pre-tared container, weighed, and dried in an oven at $105^{\circ} \mathrm{C}$ until constant weight was achieved (in triplicate). At least two weighings, each after a 24-hour heating, was performed to verify that all moisture was removed.

In addition to the moisture analyses, a series of resin digestion experiments were conducted in an attempt to quantify the total amount of ${ }^{99} \mathrm{Tc}$ retained on the ion exchange resin. After several iterations and attempts to dissolve the resin using varying concentrations of $\mathrm{H}_{2} \mathrm{O}_{2}$ mixed with $0.025 \mathrm{moL} / \mathrm{L}$ $\mathrm{Fe}\left(\mathrm{NO}_{3}\right)_{3}$ and applying heat, the resin beads did not dissolve. Previous exchange analyses were conducted using samples of spent resin from the pilot scale treatability test and the results suggest a ${ }^{99} \mathrm{Tc}$ loading value of $2.08 \times 10^{5} \mathrm{pCi} / \mathrm{g}\left(\sim 12.5 \mu \mathrm{g} / \mathrm{g}{ }^{99} \mathrm{Tc}\right)$. This value will be used as the total ${ }^{99} \mathrm{Tc}$ loaded on the resin for the purposes of these experiments. 


\subsection{Long Term Stability}

Due to long-term storage of the re-hydrated spent ion exchange resin columns, the resin may have degraded and released some of the ${ }^{99} \mathrm{Tc}$ adsorbed on the resin. Because ${ }^{99} \mathrm{Tc}$ is highly mobile and generally non-adsorptive, ${ }^{99} \mathrm{Tc}$ that is released from the resin because of degradation is assumed to be leachable with deionized water (Krupka and Serne 2002). To evaluate whether the ${ }^{99} \mathrm{Tc}$ has desorbed from the spent resin, a series of leaching tests was conducted using deionized water extractions. The extracts were prepared by adding a known weight to approximately 5 to 20 grams of resin at 1:1, 1:2 and 1:5 solid-to-solution ratios (see Table 2.1). The weight of deionized water needed was calculated, accounting for the existing moisture in the resin based on measurements obtained from moisture content tests. An appropriate amount of deionized water was added to screw cap jars containing a known amount of resin. The jars were then sealed and placed on a mechanical orbital shaker for 2 hours of contact. The supernatant was decanted and filtered and submitted for ${ }^{99} \mathrm{Tc}$ analysis by inductively coupled plasma mass spectroscopy (ICP-MS).

Table 2.1. Schedule for Long Term Stability Tests

\begin{tabular}{ccc}
\hline Sample & $\begin{array}{c}\text { Solid:Solution } \\
\text { Ratio }\end{array}$ & $\begin{array}{c}\text { Resin (dry) mass } \\
(\mathrm{g})\end{array}$ \\
\hline S01 & $1: 1$ & 20 \\
S02 & $1: 2$ & 10 \\
S03 & $1: 5$ & 5 \\
\hline Note: samples conducted in duplicate & \\
\hline
\end{tabular}

An additional leach test was conducted to evaluate whether ${ }^{99} \mathrm{Tc}$ measured in the solutions from the leach tests was a contribution from the ${ }^{99} \mathrm{Tc}$ that desorbed from the resin or ${ }^{99} \mathrm{Tc}$ that was contained in the interstitial pore water. The extract was prepared using a solid-to-solution ratio of 1:2. The extract was prepared the same as the previous leach tests, but after 2 hours of contact, the solution was decanted, and new deionized water (the same amount) was added back to the resin. The jars were sealed and returned to the mechanical orbital shaker. Decanting and replacing the deionized water contacted with the resin took place over a period of 4 days with sampling and water replacement occurring at 2 hours, 6 hours, 1 day, 2 days, 3 days, and 4 days. After decanting the deionized water, the solution was filtered and submitted for ${ }^{99}$ Tc analysis by ICP-MS.

\subsection{Stability in Heated Water}

During operation, the ion exchange resin will be treated with a combination of hot water and air sparging to remove adsorbed carbon tetrachloride. The temperature of the heated water is expected to fall between $\sim 40$ and $75^{\circ} \mathrm{C}$ and last an estimated 16 hours at these temperatures. The Purolite A530E resin can withstand temperatures from $100^{\circ} \mathrm{C}$ to $-40^{\circ} \mathrm{C}$ (Purolite 2007, 2009). To evaluate the resin's stability under heated conditions, a series of leaching tests at 40,60 , and $80^{\circ} \mathrm{C}$ was conducted (in duplicate). Approximately 5 grams of resin was contacted with 10 grams of deionized water and put into an oven at temperatures of 40,60 , and $80^{\circ} \mathrm{C}$. Additional samples were prepared (a total of 6 samples at each temperature) to evaluate the release as a function of time (6,12, and 24 hours) at each temperature. At 
the end of each time interval, the samples were removed from each oven, and the heated supernatant was filtered, acidified, and analyzed for ${ }^{99}$ Tc using ICP-MS (Table 2.2).

Table 2.2. Schedule for Stability in Heated Water Test

\begin{tabular}{cccc}
\hline Sample & $\begin{array}{c}\text { Temperature } \\
\left({ }^{\circ} \mathrm{C}\right)\end{array}$ & $\begin{array}{c}\text { Contact time } \\
\text { (hours) }\end{array}$ & $\begin{array}{c}\text { Resin (dry) mass } \\
(\mathrm{g})\end{array}$ \\
\hline T01-6 & 40 & 6 & 5 \\
T01-12 & 40 & 12 & 5 \\
T01-24 & 40 & 24 & 5 \\
T02-6 & 60 & 6 & 5 \\
T02-12 & 60 & 12 & 5 \\
T02-24 & 60 & 24 & 5 \\
T03-6 & 80 & 6 & 5 \\
T03-12 & 80 & 12 & 5 \\
T03-24 & 80 & 24 & 5 \\
\hline Note: samples were conducted in duplicate \\
\hline \multicolumn{4}{c}{} \\
\hline
\end{tabular}

\subsection{Resin Stabilization for Disposal}

One option of stabilizing spent ion exchange resin is encapsulation in Portland cement or an alternative near-neutral stabilizing material, such as magnesium potassium phosphate, before placement in a permanent storage impoundment or disposal facility. The components used to prepare the monolith waste form are listed in Table 2.3 and include sulfate-resistant Portland Type I/II cement, a pozzolanic material (Class F fly ash), and deionized (DI) water. The Portland cement was obtained from LaFarge North America, Inc. (Herdon, Virginia), and the fly ash was obtained from Lonestar (Seattle, Washington).

The encapsulation monoliths (1-inch diameter by 1.8-inch height) were prepared by adding the components in the following order: cement, fly ash, spent ion exchange resin, and DI water. The amount of resin used was a maximum of $20 \%$ of the final cement mix. The dry materials were blended for 5 minutes using a planetary mixer set at low speed. After the dry material was homogeneous, the spent ion exchange resin and water were added to the blended dry mixture. The materials were mixed for 5 minutes to verify homogeneity. Polycarbonate sleeves were used as molds for casting monoliths. The molds were partially filled in the vertical position and vibrated until a significant decrease in the release of air bubbles was observed. Then, the molds were filled again with additional wet slurry and vibrated until no air bubbles were observed. This process was repeated until the molds were completely filled. The molds were stored in a 100\% relative humidity chamber for 5 days, at which time the encapsulated monoliths were removed from the molds. The monoliths were subsequently stored in the humidity chamber for an additional 23 days for a total curing time of 28 days.

After the 28-day cure time, it was noted that the monolith samples prepared using the initial receipe were crumbly in texture. Therefore, a revised recipe was created with an increase in the amount of Portland cement and fly ash (Table 2.3). After the 28-day cure time, the U.S. Environmental Protection Agency (EPA) Method 1315 was repeated for this second set of monolith samples. Only the samples collected from the final recipe were analyzed and reported here. 
Table 2.3. Recipe Encapsulation Monoliths

\begin{tabular}{lcc}
\hline Material & $\begin{array}{c}\text { Initial Recipe Quantity } \\
(\mathrm{g})\end{array}$ & $\begin{array}{c}\text { Final Recipe } \\
\text { Quantity (g) }\end{array}$ \\
\hline Resin & 20 & 20 \\
Fly ash & 48 & 51 \\
Portland cement & 9 & 18 \\
Water & 10 & 11 \\
\hline
\end{tabular}

\subsubsection{EPA Method 1315}

The high $\mathrm{pH}$ of the most common stabilizing agents-for example, cementitious material, nominally $\sim 12.5$, - may cause the release of ${ }^{99}$ Tc from the spent ion exchange resin. To evaluate the effect of immobilizing spent resin in Portland cement, EPA Draft Method 1315, Mass Transfer Rates of Constituents in Monolith or Compacted Granular Materials Using a Semi-Dynamic Tank Leaching Test, was used to provide more detailed information on ${ }^{99}$ Tc release from a stabilized form. The EPA Method 1315 is a semi-dynamic leach experiment that consists of submerging a monolithic sample (with a fixed geometry) in DI water at a fixed liquid volume-to-solid surface area ratio and sampling at fixed periods of time as cumulative leaching times (EPA 2009c). At each sampling interval, the leaching fluid is removed and replaced with fresh fluid. A schematic of this process is shown in Figure 2.1. Here we performed a shorter duration test for 14 days in duplicate to evaluate ${ }^{99}$ Tc release.

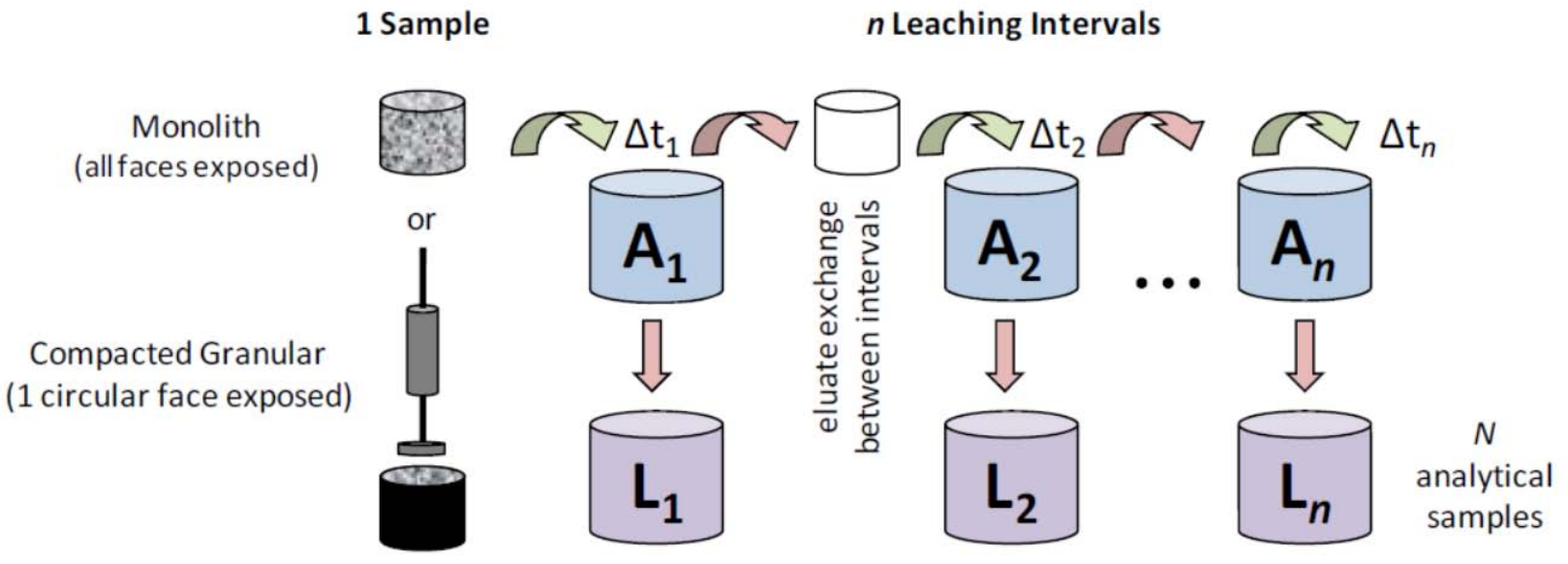

Figure 2.1. Schematic of 1315 Test Method

The geometric surface area is used in this test method and is calculated based on the cylindrical dimensions of the sample. The average calculated geometric surface area was $0.0046 \pm 0.0001 \mathrm{~m}^{2}$. At each of the seven pre-determined leaching intervals, the sample mass was recorded, and the leaching solution was changed. This method is similar to the American National Standards Institute/American Nuclear Society (ANSI/ANS) 16.1 (ANSI 1986), but the leaching intervals are modified, and the process of mass transfer can be interpreted by more complex release models that account for physical retention of the porous medium and chemical retention at the pore wall through geochemical speciation modeling. 
The cylindrical monolith sample (1-inch diameter by 1.8-inch height) was placed into the center of a leaching vessel and mixed with DI water to maintain a solid-to-solution ratio of $10 \pm 1 \mathrm{~mL}$ of eluant per $\mathrm{cm}^{2}$ of sample. The sample stand and holder were used to maximize the contact area of the sample with the leaching solution. In between the sampling/replacement intervals, the experimental vessels were covered with a lid. An example of the experimental setup and sample specimens in the leaching vessels is shown in Figure 2.1. The leaching times at which solution exchanges were made for these experiments were $0.08,0.25,1,2,7$, and 14 days. Leachate samples collected during these intervals were used to measure $\mathrm{pH}$. Before submitting for chemical analyses, the samples were also filtered using a $0.45-\mu \mathrm{m}$ syringe filter.

Table 2.4. Schedule for Resin Stability (Method 1315) Experiment

\begin{tabular}{cccc}
\hline Sample & $\begin{array}{c}\text { Interval duration } \\
\text { (hours) }\end{array}$ & $\begin{array}{c}\text { Interval duration } \\
\text { (days) }\end{array}$ & $\begin{array}{c}\text { Cumulative leaching } \\
\text { time (days) }\end{array}$ \\
\hline T01 & $2.0 \pm 0.25$ & & 0.08 \\
T02 & $23.0 \pm 0.5 \pm$ & & 1.0 \\
T03 & $23.0 \pm 0.5$ & $5.0 \pm 0.1$ & 2.0 \\
T04 & & $7.0 \pm 0.1$ & 7.0 \\
T05 & & 14.0 \\
\hline Note: samples will be conducted in duplicate & \\
\hline
\end{tabular}

The observed diffusivity for each constituent was calculated using the analytical solution, Equation (2.1), for simple radial diffusion from a cylinder into an infinite bath as presented by Crank (1986):

$$
D_{i}=\pi\left[\frac{M_{t_{i}}}{2 \rho C_{o}\left(\sqrt{t_{i}}-\sqrt{t_{i-1}}\right)}\right]^{2}
$$

where $\quad D_{i}=$ observed diffusivity of a specific constituent for leaching interval $i\left[\mathrm{~m}^{2} / \mathrm{s}\right]$

$M_{t i}=$ mass released during leaching interval $i\left[\mathrm{mg} / \mathrm{m}^{2}\right]$

$t_{i}=$ cumulative contact time after leaching interval, $i[\mathrm{~s}]$

$t_{i-1}=$ cumulative contact time after leaching interval, $i-1[\mathrm{~s}]$

$C_{o}=$ initial leachable content $[\mathrm{mg} / \mathrm{Kg}]$

$\rho=$ sample density $\left[\mathrm{Kg}-\mathrm{dry} / \mathrm{m}^{3}\right]$.

The mean observed diffusivity for each constituent can be determined by taking the average of the interval observed diffusivity with the standard deviation. The Leachability Index $(L I)$, the parameter derived directly from immersion test results, evaluates diffusion-controlled contaminant release with respect to time. The $L I$ is used as a performance criterion to assess whether solidified/stabilized waste will likely be acceptable for subsurface disposal in waste repositories. In most cases, the solidified waste is considered effectively treated when the $L I$ value is equal to or greater than nine. The $L I$ is calculated with Equation (2.2).

$$
L I_{n}=-\log \left(\frac{D_{n}}{c m^{2} s}\right)
$$


where $L I$ is the leach index, and $D_{n}$ is the effective diffusivity for elements of interest $\left(\mathrm{cm}^{2} / \mathrm{s}\right)$ during the leach interval $n$. 


\subsection{Results and Discussion}

\subsection{Ion Exchange Resin Moisture and Re-hydration}

The results from the moisture contents conducted on the as-received and re-hydrated resin are shown in Table 3.1. After long-term storage, the moisture content results confirm that the resin became dehydrated while it was being stored. Analysis of the saturating solution used to re-hydrate the resin resulted in $9.6 \mathrm{E}+3 \mathrm{pCi}$ of ${ }^{99} \mathrm{Tc}$. However, it is not known whether the ${ }^{99} \mathrm{Tc}$ contained in the re-hydrating solution was desorbed from the resin or was contained in the interstitial pore spaces of the resin.

Table 3.1. Moisture Content Results for the as-Received and Re-Hydrated Resin

\begin{tabular}{ccc}
\hline & $\begin{array}{c}\text { Moisture } \\
\text { Content (\%) }\end{array}$ & $\begin{array}{c}\text { Standard } \\
\text { Deviation }\end{array}$ \\
\hline as-received & 0.78 & $1.62 \mathrm{E}-02$ \\
re-hydrated & 1.4 & $4.03 \mathrm{E}-02$ \\
\hline
\end{tabular}

\subsection{Long-Term Stability}

The results for the long-term stability leach tests are shown in Figure 3.1. The concentration of ${ }^{99} \mathrm{Tc}$ detected in the different solid-to-solution ratios resulted in 26 to $37 \mathrm{pCi} / \mathrm{g}$ of ${ }^{99} \mathrm{Tc}$. With respect to the starting concentration of ${ }^{99} \mathrm{Tc}$ in the resin, these results indicate that less than $0.02 \%$ of the total amount of ${ }^{99} \mathrm{Tc}$ was released from the resin during the leach tests. Additionally, the follow-up leach tests with the replacement of the deionized water over a 4-day time period are shown in Figure 3.2. There was a slight decrease in the concentration of ${ }^{99} \mathrm{Tc}$ each time the deionized water was replaced, with the largest decrease occurring after the 2-hour exchange. This decrease indicates that there was a likely a small contribution of ${ }^{99} \mathrm{Tc}$ that came from ${ }^{99} \mathrm{Tc}$ remaining in the pore spaces of the resin. However, the total amount of ${ }^{99} \mathrm{Tc}$ found in the solution was less than $0.005 \%$ of the total ${ }^{99} \mathrm{Tc}$ contained in the resin. 


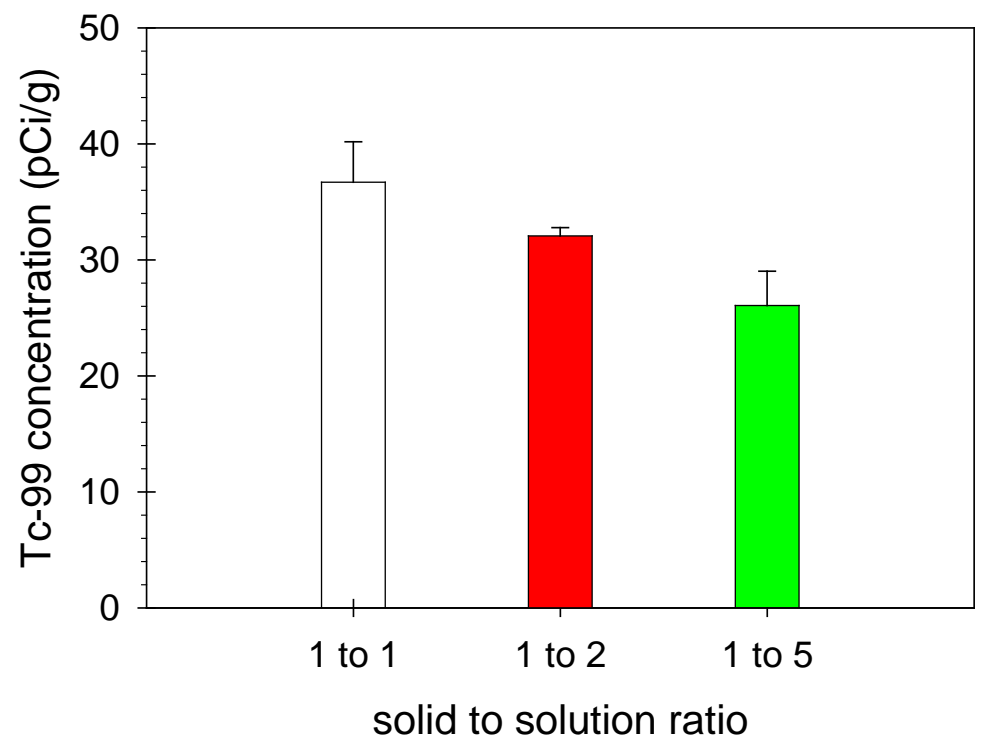

Figure 3.1. Results of the Long-Term Stability Leach Tests at Varying Solid-to-Solution Ratios

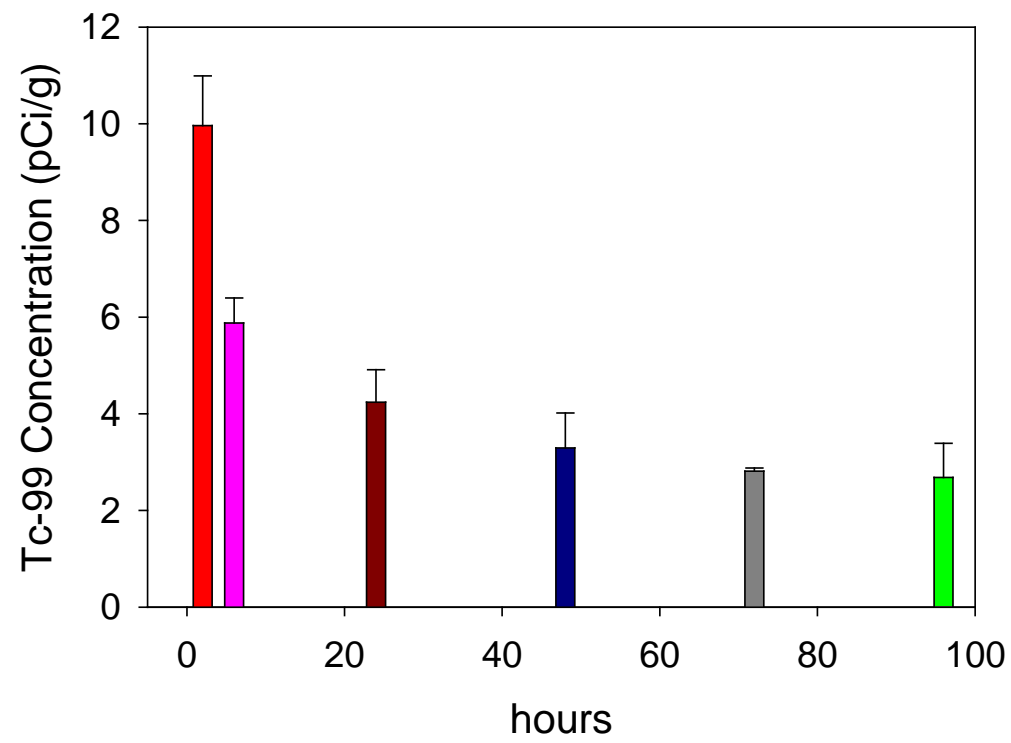

Figure 3.2. Results of the Additional Leach Test with Replacement of Deionized Water 


\subsection{Stability in Heated Water}

The results for the long-term stability leach tests conducted at different temperatures are displayed in Figure 3.3. The largest increase in ${ }^{99} \mathrm{Tc}$ concentration occurred in the $80^{\circ} \mathrm{C}$ samples. The difference between the 6-hour and 24-hour ${ }^{99} \mathrm{Tc}$ concentrations at $80^{\circ} \mathrm{C}$ yielded a $14 \%$ difference. However, even the highest concentration of ${ }^{99} \mathrm{Tc}$ found at $80^{\circ} \mathrm{C}, 24$ hours, is less than $0.02 \%$ leached of the total starting ${ }^{99} \mathrm{Tc}$ found in the resin. The percent leached from the heated water leach tests ranges from $0.013 \%$ to $0.019 \%$.

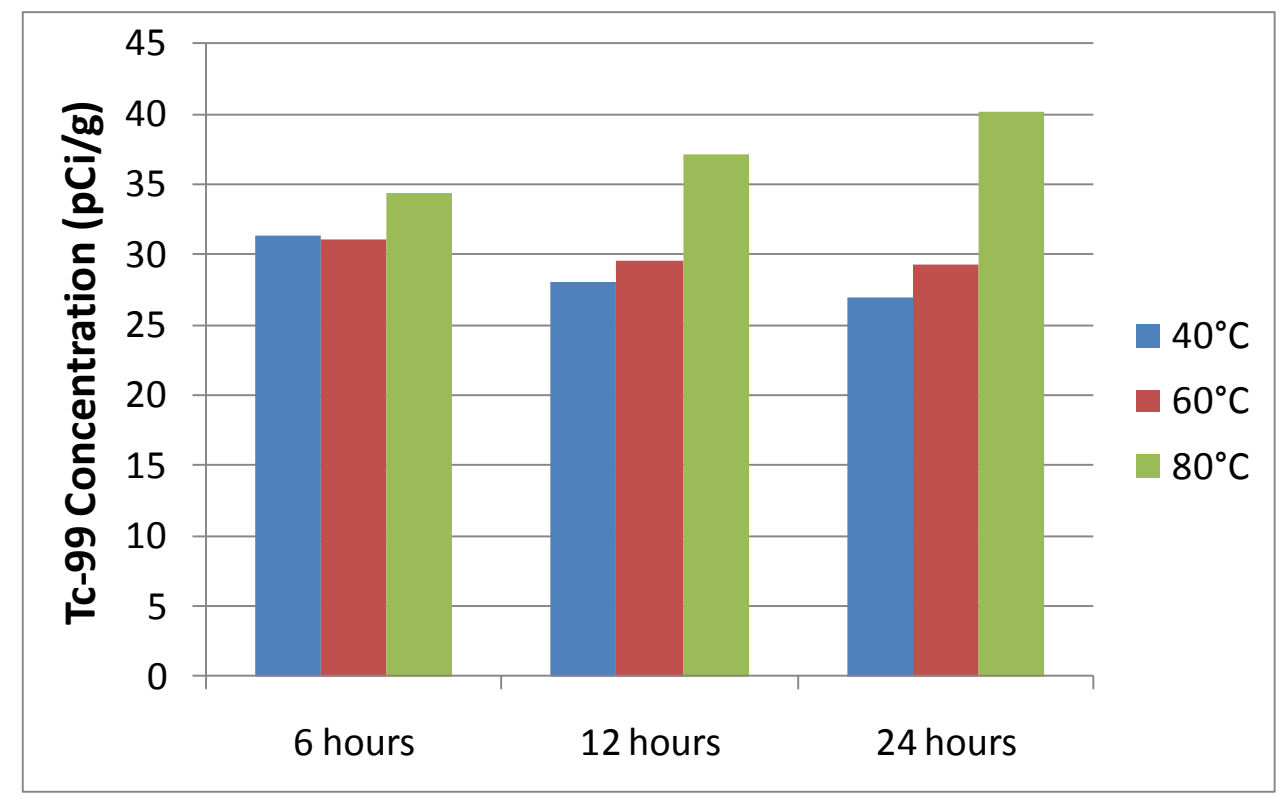

Figure 3.3. Results of the Long-Term Stability Tests at Varying Temperatures

\subsection{Resin Stabilization for Disposal}

In this section, we discuss the results obtained from immobilizing spent ion exchange resin in a mixture of Portland cement and fly ash. We begin by discussing the results obtained from characterizing the raw materials (e.g., portland cement and fly ash) used to prepare the monolith samples of encapsulated resin. This section is followed by a presentation of the results obtained from EPA Method 1315.

\subsection{Solids Characterization}

The raw materials used to prepare the waste forms and the 28-day cured portland cement samples were characterized with respect to their crystalline and chemical composition using a variety of techniques, including chemical digestion, X-ray diffraction (XRD), and scanning electron microscopy (SEM) with energy dispersive spectrometry (EDS). The results from these analyses are discussed in the sections that follow. 
Table 3.2. Chemical Composition, in $\mu \mathrm{g} / \mathrm{g}$, of Raw Materials Used for Monolith Samples_Fly Ash and Portland Cement

\begin{tabular}{|c|c|c|}
\hline Elements & Fly Ash & Portland Cement \\
\hline Tc & $\mathrm{NA}^{(\mathrm{a})}$ & NA \\
\hline $\mathrm{Al}$ & $4.87 \mathrm{E}+03$ & $8.97 E+04$ \\
\hline $\mathrm{Ag}$ & $2.05 E+00$ & $2.20 \mathrm{E}+00$ \\
\hline As & $<7.99 \mathrm{E}-03$ & $1.50 \mathrm{E}+01$ \\
\hline $\mathrm{Ba}$ & $2.45 \mathrm{E}+02$ & $2.18 \mathrm{E}+03$ \\
\hline Ca & $4.67 \mathrm{E}+05$ & $4.74 \mathrm{E}+04$ \\
\hline $\mathrm{Cd}$ & $<1.32 \mathrm{E}-03$ & $<1.32 \mathrm{E}-03$ \\
\hline $\mathrm{Cr}$ & $6.87 \mathrm{E}+01$ & $3.60 \mathrm{E}+01$ \\
\hline $\mathrm{Cu}$ & $1.16 \mathrm{E}+02$ & $1.20 \mathrm{E}+02$ \\
\hline $\mathrm{Fe}$ & $2.01 \mathrm{E}+04$ & $3.97 \mathrm{E}+04$ \\
\hline $\mathrm{Hg}$ & 7.14E-02 & 6.69E-02 \\
\hline I & $<5.75 \mathrm{E}-01$ & $<5.75 \mathrm{E}-01$ \\
\hline K & $2.13 \mathrm{E}+03$ & $4.17 \mathrm{E}+03$ \\
\hline $\mathrm{Mg}$ & $5.70 \mathrm{E}+03$ & $7.69 \mathrm{E}+03$ \\
\hline $\mathrm{Mn}$ & $5.16 \mathrm{E}+02$ & $3.22 \mathrm{E}+02$ \\
\hline $\mathrm{Na}$ & $3.74 \mathrm{E}+03$ & $3.23 E+04$ \\
\hline $\mathrm{P}$ & $6.16 \mathrm{E}+02$ & $4.06 \mathrm{E}+03$ \\
\hline $\mathrm{Pb}$ & $2.15 E+01$ & $2.13 \mathrm{E}+01$ \\
\hline $\mathrm{S}$ & $1.24 \mathrm{E}+04$ & $1.01 \mathrm{E}+03$ \\
\hline $\mathrm{Si}$ & $1.01 \mathrm{E}+05$ & $2.02 E+05$ \\
\hline Sn & $6.01 \mathrm{E}+02$ & $9.16 \mathrm{E}+01$ \\
\hline $\mathrm{Sr}$ & $1.20 \mathrm{E}+03$ & $3.10 \mathrm{E}+03$ \\
\hline $\mathrm{Ti}$ & $1.59 \mathrm{E}+03$ & $2.34 \mathrm{E}+04$ \\
\hline $\mathrm{V}$ & $9.05 E+01$ & $4.88 \mathrm{E}+02$ \\
\hline $\mathrm{Zn}$ & $6.87 \mathrm{E}+02$ & $1.91 \mathrm{E}+02$ \\
\hline $\mathrm{Zr}$ & $3.88 \mathrm{E}+02$ & $8.93 E+02$ \\
\hline
\end{tabular}

Powder XRD measurements were performed on the raw ingredients used to prepare the encapsulation monolith samples. The measured XRD patterns are shown in Figure 3.4 along with the standard mineral powder diffraction files $\left(\mathrm{PDF}^{\mathrm{TM}}\right)$. The fly ash (Figure 3.4) XRD pattern suggests that this material is amorphous with minor amounts of crystalline phases. The peak near $26.7^{\circ} 2 \theta$ was identified as quartz (PDF\#00-046-1045, $\mathrm{SiO}_{2}$ ). The identification of the peak near $35.5^{\circ} 2 \theta$ may be magnetite (PDF\# 00-0190629, $\mathrm{Fe}_{3} \mathrm{O}_{4}$ ). However, this is not certain. The portland cement type I/II XRD pattern suggests that this raw ingredient contains a significant amount of crystalline material. Calcium silicate (PDF\# 00-0550740, $\mathrm{Ca}_{3} \mathrm{SiO}_{5}$ ) was the dominant crystalline phase identified in the XRD pattern (see Figure 3.4), which is typical of portland cement. Although additional Rietveld refinements (Rietveld 1969) are needed for conclusive identification, these results further suggest that the dominant form of calcium silicate present 
is the monoclinic type-2 polymorph. Additionally, a minor amount of dolomite (PDF\# 98-000-0200, $\left.\mathrm{MgCa}\left(\mathrm{CO}_{3}\right)_{2}\right)$ was also observed in the portland cement.
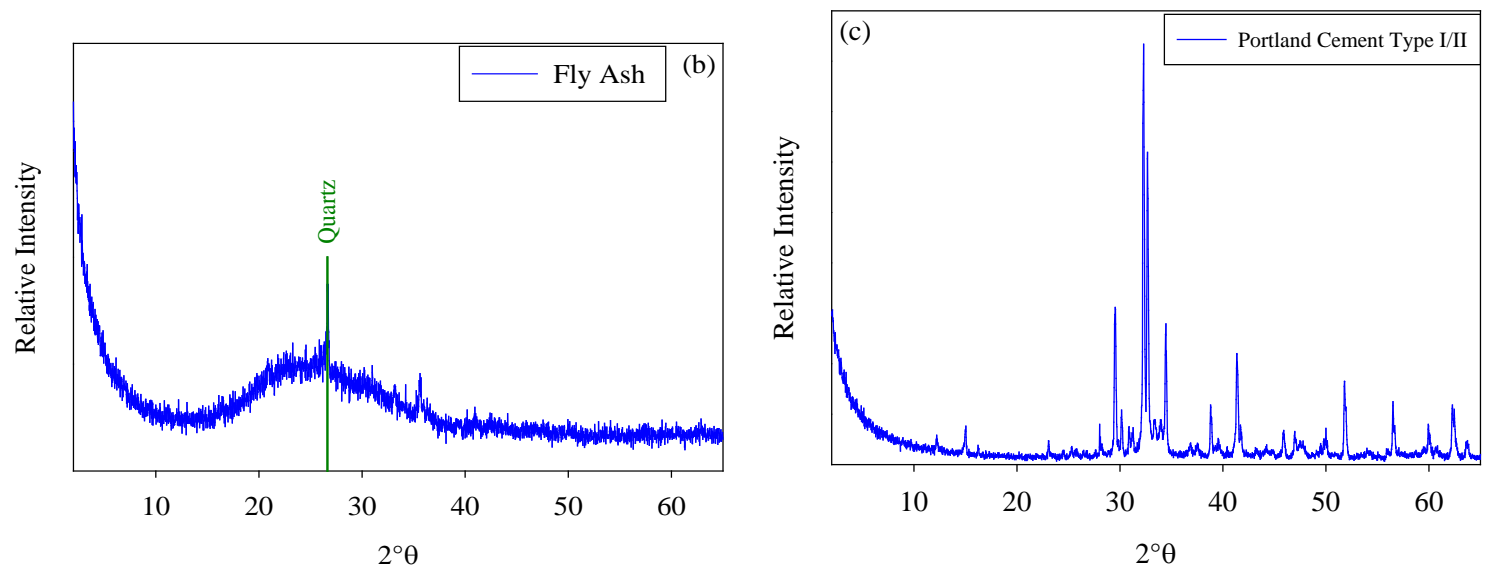

Figure 3.4. X-Ray Diffraction Patterns for Raw Materials—Fly Ash (left) and Portland Cement Type II (right)

A low magnification image of a cluster of fly ash grains is shown in Figure 3.5. This image reveals that the morphology of the unreacted fly ash is primarily spherical with a range of particle sizes. The shape and the morphology of the fly ash particles are typical and are the results of how these particles are produced. Fly ash is a residue material generated in the combustion of coal and solidifies while suspended in exhaust gases. The EDS spectrum reveals a high silicon and Al content for the spherical particles that contain a minor amount of calcium, iron, sodium, magnesium, and titanium. Based upon the amorphous XRD pattern, chemical digestion, and SEM/EDS, one can conclude that these spherical particles are mainly an amorphous $\mathrm{SiO}_{2}$ phase that has become a host matrix for other cations and mineral phases. 


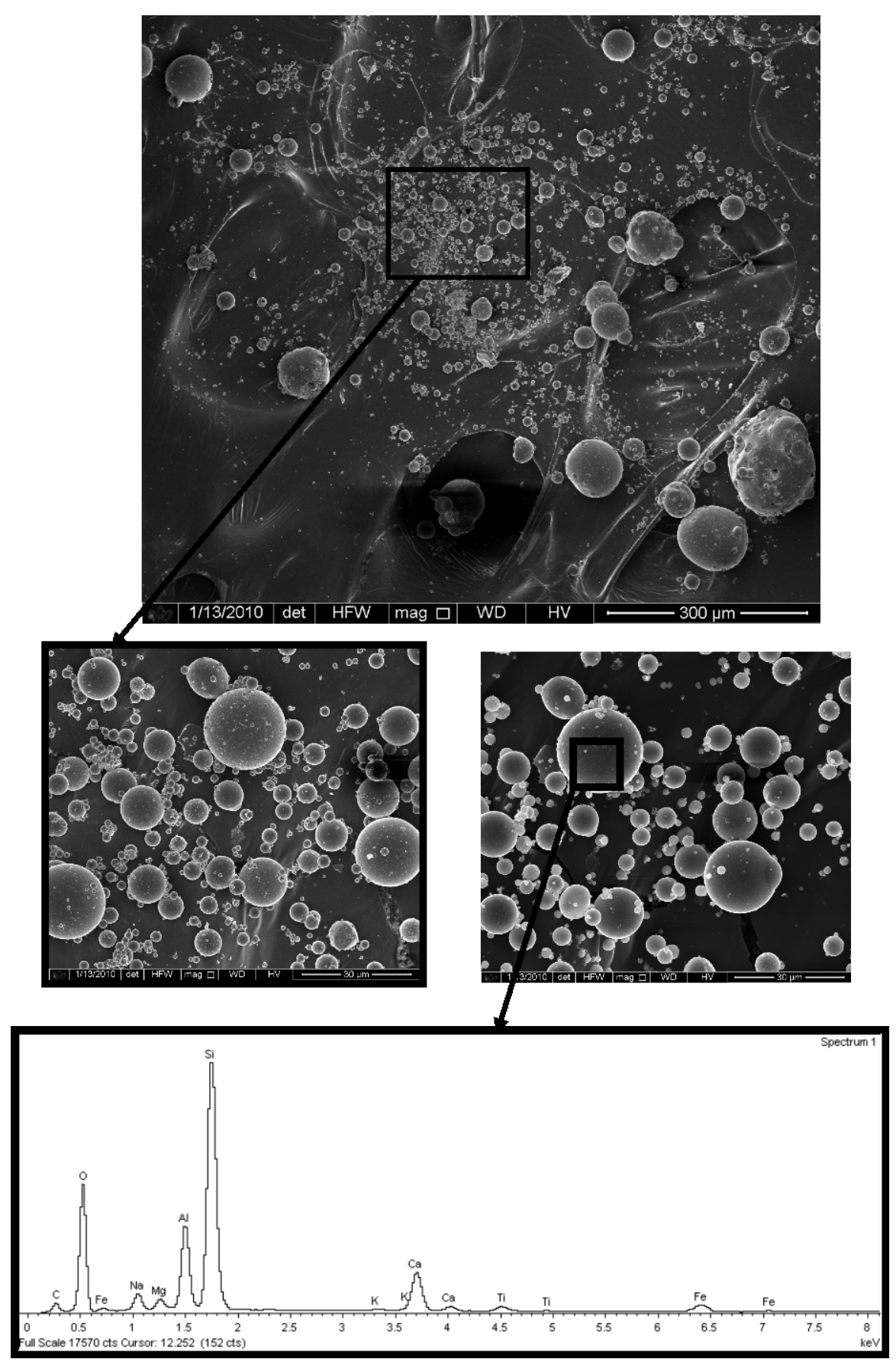

Figure 3.5. Fly Ash SEM Images and EDS Spectrum. The top image is a low-magnification ( 300 $\mu \mathrm{m})$ image of fly ash with an increased magnification of multiple spheres at $30 \mu \mathrm{m}$ (center left). The additional image (center right) was used to collect EDS spectra of a sphere of fly ash (bottom).

Figure 3.6 is a low-magnification micrograph that shows the morphologies, sizes, and surface textures of typical portland cement particles. Analysis of the SEM micrographs indicates that the aggregates of portland cement are made up primarily of a single phase. The EDS spectrum reveals a high calcium and 
silicon content with minor amounts of aluminum, calcium, iron, magnesium, and sulfur. These results are consistent with the XRD identification (Figure 3.4c) and chemical digestion results (Table 3.2).

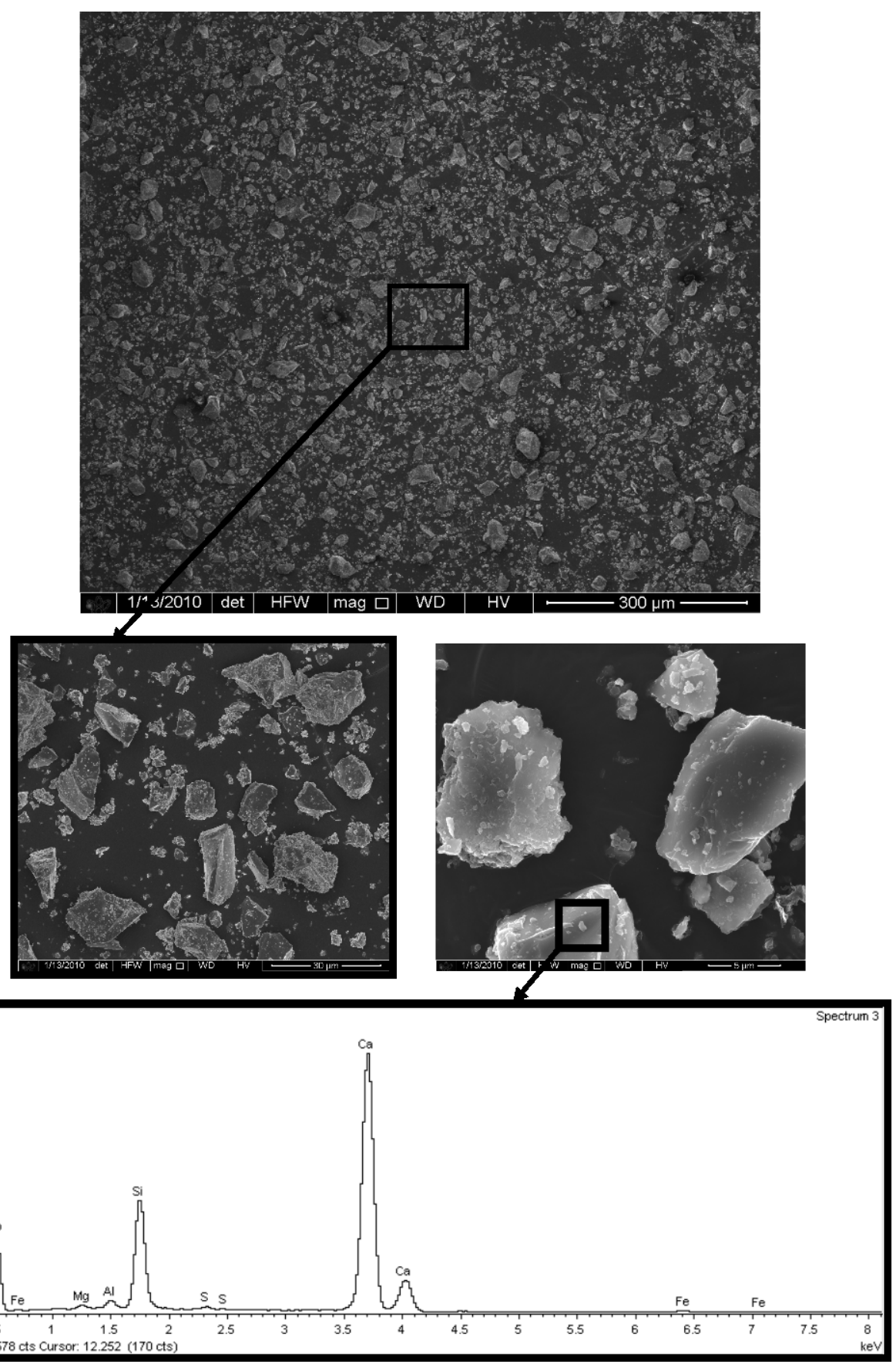

Figure 3.6. Portland Cement SEM Images and EDS Spectrum. The top image is a low-magnification $(\sim 300 \mu \mathrm{m})$ image of portland cement with an increased magnification of multiple spheres at $30 \mu \mathrm{m}$ (center left). The additional image (center right) was used to collect EDS spectra of portland cement (bottom). 


\subsection{EPA 1315 Monolith Results}

The monoliths created for the Method 1315 experiments resulted in cylinders that have a mass of 37.7 to 38.9 grams, a surface area of 45.6 to $48.3 \mathrm{~cm}^{2}$, and a volume of approximately 0.02 liters. The first monolith that was tested (recipe above in Table 2.3) resulted in ${ }^{99}$ Tc concentrations of approximately $17,000 \mathrm{pCi} / \mathrm{g}$. These concentrations indicate that approximately $0.08 \%$ of the total ${ }^{99} \mathrm{Tc}$ contained in the resin was leached from the portland cement monoliths.

The second set of monoliths that contain an increase in the quantity of cement used (recipe in Table 2.3) resulted in monoliths that visually looked sturdier in construction and were not crumbling. The ${ }^{99} \mathrm{Tc}$ concentrations in these solutions were below the ICP-MS estimated quantification limit $(\mathrm{EQL}=0.02 \mu \mathrm{g} / \mathrm{L})$. Using the EQL value, the upper limit for the diffusivity and LI was calculated for these results, and the results are provided in Table 3.3. It is important to note that these are short-term leach tests, and the intent of these results is to provide an initial indication as to whether solidification in a cementitious waste form would be a viable option.

Table 3.3. Average Diffusivity and LI Values for Encapsulated Spent Resin

\begin{tabular}{ccc}
\hline $\begin{array}{c}\text { Cumulative } \\
\text { Leaching Time } \\
\text { (days) }\end{array}$ & $\begin{array}{c}\text { Tc } \\
\text { Diffusivity } \\
\left(\mathrm{cm}^{2} / \mathrm{s}\right)\end{array}$ & LI \\
\hline 0.08 & $<1.07 \mathrm{E}-14$ & 14.0 \\
1 & $<1.77 \mathrm{E}-15$ & 14.8 \\
2 & $<5.22 \mathrm{E}-15$ & 14.3 \\
8 & $<4.47 \mathrm{E}-16$ & 15.3 \\
14 & $<1.07 \mathrm{E}-15$ & 15.0 \\
\hline
\end{tabular}

\subsection{Discussion}

The distribution coefficient $\left(K_{d}\right)$ is a measure of sorption and is defined as the ratio of the amount of an adsorbate sorbed on a solid to the amount of adsorbate still in solution at equilibrium (EPA 1999). The expression is as follows:

$$
K_{d}=\frac{A_{i}}{C_{i}}
$$

where $A_{i}$ is the adsorbate on the solid at equilibrium $\left(\mu \mathrm{g} \mathrm{g}^{-1}\right)$, and $C_{i}$ is the adsorbate remaining in solution at equilibrium $\left(\mu \mathrm{g} \mathrm{mL}^{-1}\right)$.

The distribution coefficient $\left(K_{d}\right)$ calculated for each experiment is shown below in Table 3.3 through Table 3.6. In oxic environments, technetium is present as Tc(VII). Technetium(VII) is not adsorptive and has high mobility, which results in $K_{d}$ values of approximately $0 \mathrm{~mL} / \mathrm{g}$ (Krupka and Serne 2002).

The $K_{d}$ values ranged from $19,000 \mathrm{~mL} / \mathrm{g}$ to $216,000 \mathrm{~mL} / \mathrm{g}$. The largest difference in the calculated $K_{d}$ values was in the long-term stability leach tests where the solid-to-solution ratio was varied. The smallest $K_{d}$ was calculated at the 1:1 solid-to-solution ratio, and the largest $K_{d}$ was at the 1:5 solid-to-solution ratio. This increase in $K_{d}$ displays the high sorption capacity of the resin. Although there were more available 
sorption sites with the additional water, the resin still continued to sorb more than $99.9 \%$ of the Tc as shown by the increase in $K_{d}$ values. The long-term stability leach tests resulted in a decrease in the $K_{d}$ values with an increase in heat. The average $K_{d}$ value at $40^{\circ} \mathrm{C}$ was approximately $53,300 \mathrm{~mL} / \mathrm{g}$, the average at $60^{\circ} \mathrm{C}$ was $50,600 \mathrm{~mL} / \mathrm{g}$, and the average at $80^{\circ} \mathrm{C}$ was $41,400 \mathrm{~mL} / \mathrm{g}$, resulting in a more than $10,000 \mathrm{~mL} / \mathrm{g}$ difference in the $K_{d}$ value from the lowest to the highest temperature. The $25 \%$ decrease in $K_{d}$ value at the higher temperature suggests that an increase in temperature causes the resin to release more Tc at higher temperatures than at lower temperatures.

Table 3.4. $K_{d}$ Results of the Long-Term Stability Leach Tests at Varying Solid to Solution Ratios

\begin{tabular}{cc}
\hline $\begin{array}{c}\text { Solid:Solution } \\
\text { Ratio }\end{array}$ & $K_{d}(\mathrm{~mL} / \mathrm{g})$ \\
\hline $1: 1$ & $1.93 \mathrm{E}+04$ \\
$1: 1$ & $2.21 \mathrm{E}+04$ \\
$1: 2$ & $4.74 \mathrm{E}+04$ \\
$1: 2$ & $5.37 \mathrm{E}+04$ \\
$1: 5$ & $2.04 \mathrm{E}+05$ \\
$1: 5$ & $2.16 \mathrm{E}+05$ \\
\hline
\end{tabular}

Table 3.5. $K_{d}$ Results of the Long-Term Stability Tests at Varying Temperatures

\begin{tabular}{ccc}
\hline $\begin{array}{c}\text { Temperature } \\
\left({ }^{\circ} \mathrm{C}\right)\end{array}$ & $\begin{array}{c}\text { Contact } \\
\text { time }\end{array}$ & $K_{d}(\mathrm{ml} / \mathrm{g})$ \\
\hline 40 & 6 & $4.95 \mathrm{E}+04$ \\
40 & 6 & $5.44 \mathrm{E}+04$ \\
40 & 12 & $5.07 \mathrm{E}+04$ \\
40 & 12 & $5.81 \mathrm{E}+04$ \\
40 & 24 & $4.92 \mathrm{E}+04$ \\
40 & 24 & $5.80 \mathrm{E}+04$ \\
\hline 60 & 6 & $4.61 \mathrm{E}+04$ \\
60 & 6 & $5.20 \mathrm{E}+04$ \\
60 & 12 & $5.09 \mathrm{E}+04$ \\
\hline 60 & 12 & $4.51 \mathrm{E}+04$ \\
60 & 24 & $5.28 \mathrm{E}+04$ \\
\hline 60 & 24 & $5.67 \mathrm{E}+04$ \\
\hline 80 & 6 & $4.33 \mathrm{E}+04$ \\
\hline 80 & 6 & $4.39 \mathrm{E}+04$ \\
\hline 80 & 12 & $4.13 \mathrm{E}+04$ \\
\hline 80 & 12 & $4.22 \mathrm{E}+04$ \\
80 & 24 & $4.04 \mathrm{E}+04$ \\
80 & 24 & $3.75 \mathrm{E}+04$ \\
\hline
\end{tabular}


Table 3.6. $K_{d}$ Results from the Long-Term Stability Leach Test

\begin{tabular}{cc}
\hline $\begin{array}{c}\text { Cumulative Time } \\
\text { Elapsed (hours) }\end{array}$ & $K_{d}(\mathrm{~mL} / \mathrm{g})$ \\
\hline 2 & $1.51 \mathrm{E}+05$ \\
2 & $1.77 \mathrm{E}+05$ \\
6 & $2.69 \mathrm{E}+05$ \\
6 & $2.97 \mathrm{E}+05$ \\
24 & $3.63 \mathrm{E}+05$ \\
24 & $4.48 \mathrm{E}+05$ \\
48 & $4.64 \mathrm{E}+05$ \\
48 & $5.73 \mathrm{E}+05$ \\
72 & $6.12 \mathrm{E}+05$ \\
72 & $5.56 \mathrm{E}+05$ \\
96 & $5.33 \mathrm{E}+05$ \\
96 & $7.36 \mathrm{E}+05$ \\
\hline
\end{tabular}

Table 3.7. $K_{d}$ Results of the Additional Leach Test with Replacement of Deionized Water

\begin{tabular}{cc}
\hline $\begin{array}{c}\text { Cumulative } \\
\text { Time (days) }\end{array}$ & $K_{d}(\mathrm{~mL} / \mathrm{g})$ \\
\hline 0.08 & $3.85 \mathrm{E}+06$ \\
0.08 & $3.38 \mathrm{E}+06$ \\
1 & $3.13 \mathrm{E}+06$ \\
1 & $2.97 \mathrm{E}+06$ \\
2 & $4.14 \mathrm{E}+06$ \\
2 & $3.79 \mathrm{E}+06$ \\
7 & $6.33 \mathrm{E}+06$ \\
7 & $5.02 \mathrm{E}+06$ \\
14 & $3.51 \mathrm{E}+06$ \\
14 & $5.04 \mathrm{E}+06$ \\
\hline
\end{tabular}




\subsection{Conclusions and Recommendations}

The long-term stability leach test results were comparable to the heated stability test results. Both yielded ${ }^{99}$ Tc concentrations that ranged from approximately 26 to 40 or $42 \mathrm{pCi} / \mathrm{g}$, which is less than $0.02 \%$ of the total ${ }^{99} \mathrm{Tc}$ loaded on the resin. The leach test that was performed to determine whether the source of the ${ }^{99} \mathrm{Tc}$ that was found in the leach solutions was from desorption of the resin or interstitial pore spaces that yielded a maximum of $10 \mathrm{pCi} / \mathrm{g}$ (after 2 hours) and decreased over a 4-day time to $3 \mathrm{pCi} / \mathrm{g}$. These low concentrations suggest that the resin was not releasing ${ }^{99} \mathrm{Tc}$ during the leach tests and there was likely only a small contribution of ${ }^{99}$ Tc that was coming from the solution remaining in the pore spaces of the resin.

The resin stabilization for the disposal recipe had to be adjusted to accommodate the hygroscopic nature of the resin. The initial recipe yielded monolith samples that were flaky in texture and consistently leached approximately $0.08 \%$ of the total ${ }^{99}$ Tc contained in the resin over the 14 -day test period. An increase in the cement used in the recipe (double the amount) produced better monoliths that visually appeared more sturdy (less flaky) and did not release any detectable ${ }^{99} \mathrm{Tc}$ into the solution over the 14-day test period. The second portland cement recipe is a more viable option for long-term stability and disposal of the ion exchange resin.

All of the experiments that were performed on the ion exchange resin show that ${ }^{99} \mathrm{Tc}$ is not easily desorbed from the resin, even after long-term storage. The release of ${ }^{99} \mathrm{Tc}$ is not largely affected by the addition of heat. The lowest percentage of ${ }^{99} \mathrm{Tc}$ release $(0.013 \%)$ occurred at the 24 -hour interval at $40^{\circ} \mathrm{C}$, and the largest percentage of ${ }^{99}$ Tc release $(0.019 \%)$ occurred at the 24 -hour interval at $80^{\circ} \mathrm{C}$. The difference in temperature yielded a small $0.006 \%$ increase in the release of ${ }^{99}$ Tc from the resin. During operation, the ion exchange resin treatment will consist of a combination of hot water and air sparging to remove adsorbed carbon tetrachloride. The temperature of the heated water is expected to fall between $\sim 40$ and $75^{\circ} \mathrm{C}$ and last an estimated 16 hours at these temperatures. The heated water treatment falls well within the range of the experimental tests. Therefore, based on the experimental results, ${ }^{99}$ Tc release from the resin during hot water treatment would be estimated to be $<0.02 \%$ of the total ${ }^{99} \mathrm{Tc}$ load. 



\subsection{References}

ANSI, 1986. Measurement of the Leachability of Solidified Low Level Radioactive Waste by a ShortTerm Test Procedure. In: Institute, A. N. S. (Ed.). American Nuclear Society, La Grange Park, IL.

Batista JR, FX McGarvey, and AR Vieira. 2000. "The removal of percholate from waters using ionexchange resins.” In: Perchlorate in the Environment. ET Urbansky, Ed.; Kluwer/Plenum: New York, pp 135-145.

Brown GM, PV Bonnesen, BA Moyer, B Gu, SD Alexandratos, V Patel, and R Ober. 2000. "The Design of Selective Resins for The Removal of Pertechnetate And Perchlorate from Groundwater.” In:

Perchlorate in the Environment. ET Urbansky, Ed.; Kluwer/Plenum: New York, pp 155-164.

Bonnesen PV, GM Brown, LB Bavoux, DJ Presley, BA Moyer, SD Alexandratos, V Patel, and R Ober. 2000. "Development of Bifunctional Anion-Exchange Resins with Improved Selectivity and Sorptive Kinetics for Pertechnetate: Batch-Equilibrium Experiments.” Environ. Sci. Technol. 34:3761-3766.

Crank 1986

EPA-U.S. Environmental Protection Agency. 1999. Understanding Variation in Partition Coefficient, $K_{d}$, Values; Volume I: The $K_{d}$ Model, Methods of Measurement, and Application of Chemical Codes. Office of Radiation and Indoor Air and Office of Environmental Restoration, Washington, D.C.

Gehner P, RM Lowy, and G Dunford. 2009. Secondary Waste Treatment Quantity and Composition (WTP Solid Waste Streams.) RPP-RPT-42519, Rev. A, Pacific Northwest National Laboratory, Richland, Washington. Washington River Protection Solutions (WRPS), Richland, Washington.

Gregor H, J Belle, and R Marcus. 1955. "Studies on Ion-exchange Resins. XIII. Selectivity Coefficients of Quaternary Base Anion-exchange Resins Toward Univalent Anions.” J. Am. Chem. Soc. 77:27132719.

Gu B, GM Brown, SD Alexandratos, R Ober, JA Dale, and S Plant. 2000a. "Efficient Treatment of Perchlorate $\left(\mathrm{ClO}_{4^{-}}\right)$-Contaminated Groundwater with Bifunctional Anion Exchange Resins.” In: Perchlorate in the Environment. ET Urbansky, Ed., Kluwer/Plenum: New York, pp 165-176.

Gu B, GM Brown, PV Bonnesen, L Liang, BA Moyer, R Ober, and SD Alexandratos. 2000b.

"Development of Novel Bifunctional Anion-Exchange Resins with Improved Selectivity for Pertechnetate Sorption from Contaminated Groundwater.” Environ. Sci. Technol. 34:1075-1080.

Guseva, LI, GS Tikhomirova, GV Buklanov, ZZ Pkhar, and IA Lebedev (1988). “Separation and Isolation of Transplutonium Elements from Other Actinides on Ionites from Aqueous and AqueousEthanol Solutions of Sulfuric Acid.” Radiokhimiya, Vol 30, No. 1, pp. 21-25.

Herbst AK. 2002. Testing and Disposal Strategy for Secondary Wastes from Vitrification of SodiumBearing Waste at the Idaho Nuclear Technology and Engineering Center. NEEL/EXT-02-00007, Idaho National Engineering and Environmental Laboratory, Idaho Falls, Idaho.

Helfferich F. 1995. Ion Exchange. Dover Publications, New York. 
Krupka KM and RJ Serne. 2002. Geochemical Factors Affecting the Behavior of Antimony, Cobalt, Europium, Technetium, and Uranium in Vadose Sediments. PNNL-14126, Pacific Northwest National Laboratory, Richland, Washington.

Li J and J Wang. 2006. “Advances in Cement Solidification Technology for Waste Radioactive Ion Exchange Resins: A Review.” Journal of Hazardous Materials B135:443-448.

Li JF, ZG Hao, and JL Wang. 2005. "Solidification of Low-Level-Radioactive Resins in ASC-Zeolite Blends.” Nuclear Engineering and Design 235:817-820.

Marina ML, FJ Esteban, and C Poitrenaud. 1996. "Study of the influence of the co-ion nature on the nitrate-chloride ion exchange in diluted and concentrated solutions." React. Funct. Polym.

31:31-37.

Melis S, J Markos, G Cao, and M Morbidelli. 1996. "Multicomponent equilibria on ion-exchange resins.” Fluid Phase Equilib. 117:281-288.

Moyer BA, and PV Bonnesen. 1997. "Physical Factors in Anion Separations.” In: Supramolecular chemistry of anions; A Bianchi, K Bowman-James, and E Garcia-Espana, Eds., VCH, New York.

Neilson RM and P Columbo. 1982. Solidification of Ion Exchange Resin Wastes. BNL-51615, Brookhaven National Laboratory, Upton, New York.

Pan LK, BD Chang, and DS Chou. 2001. "Optimization for Solidification of Low-Level-Radioactive Resin Using Taguchi Analysis.” Waste Management 21:767-772.

Purolite. 2007. Purolite A530E Strong Base Anion Macroporous. Product Data Sheet, Bala Cynwyd, Pennsylvania.

Purolite. 2009. The Storage, Transportation and Preconditioning of Ion Exchange Resins. Purolite Product Bulletin, Bala Cynwyd, Pennsylvania.

Rietveld, HM 1969. A Profile Refinement Method for Nuclear and Magnetic Structures. Journal of Applied Crystallography, Vol. 2, pp. 65-71.

Sorg TJ, MR Schock, and DA Lytle. 1999. “Ion Exchange Softening: Effects on Metal Concentrations.” J. Am. Water Works Assoc. 91:85-97.

Speranzini RA and LP Buckley. 1981. Treatment of Spent Ion-Exchange Resins for Disposal. AECL7411, Atomic Energy Canada-Chalk River Nuclear Laboratories, Chalk River, Ontario, Canada.

Tao Z and R Xiao. 1996. "Studies on ion exchange equilibria and kinetics VI. Prediction of ion exchange equilibria of $\mathrm{UO}_{2}{ }^{2+}-\mathrm{Na}^{+}-\mathrm{H}^{+}$ternary system.” J. Radioanal. Nucl. Chem. 207:71-79.

Tripp AR and DA Clifford. 2000. "The Treatability of Perchlorate in Groundwater Using Ion-Exchange Technology.” In: Perchlorate in the Environment; ET Urbansky, Ed.; Kluwer/Plenum: New York, pp 123-134. 


\section{Appendix A}

Technetium-99 Analytical Results from Long-Term Stability Experiment

\begin{tabular}{cc}
\hline $\begin{array}{c}\text { Solid:Solution } \\
\text { Ratio }\end{array}$ & $\begin{array}{c}{ }^{99} \mathrm{Tc} \\
(\mu \mathrm{g} / \mathrm{L})\end{array}$ \\
\hline $1: 1$ & $9.93 \mathrm{E}-01$ \\
$1: 1$ & $8.67 \mathrm{E}-01$ \\
$1: 2$ & $5.77 \mathrm{E}-01$ \\
$1: 2$ & $5.34 \mathrm{E}-01$ \\
$1: 5$ & $2.59 \mathrm{E}-01$ \\
$1: 5$ & $2.32 \mathrm{E}-01$ \\
\hline
\end{tabular}

Technetium-99 Analytical Results from Stability in Hot Water Experiments

\begin{tabular}{ccc}
\hline $\begin{array}{c}\text { Temperature } \\
\left({ }^{\circ} \mathrm{C}\right)\end{array}$ & $\begin{array}{c}\text { Contact Time } \\
\text { (hours) }\end{array}$ & $\begin{array}{c}{ }^{99} \mathrm{Tc} \\
(\mu \mathrm{g} / \mathrm{L})\end{array}$ \\
\hline 40 & 6 & $5.51 \mathrm{E}-01$ \\
40 & 6 & $5.33 \mathrm{E}-01$ \\
40 & 12 & $5.23 \mathrm{E}-01$ \\
40 & 12 & $4.78 \mathrm{E}-01$ \\
40 & 24 & $5.19 \mathrm{E}-01$ \\
40 & 24 & $4.70 \mathrm{E}-01$ \\
60 & 6 & $5.69 \mathrm{E}-01$ \\
60 & 6 & $5.40 \mathrm{E}-01$ \\
60 & 12 & $5.34 \mathrm{E}-01$ \\
60 & 12 & $5.61 \mathrm{E}-01$ \\
60 & 24 & $5.27 \mathrm{E}-01$ \\
60 & 24 & $4.92 \mathrm{E}-01$ \\
80 & 6 & $6.33 \mathrm{E}-01$ \\
80 & 6 & $6.04 \mathrm{E}-01$ \\
80 & 12 & $6.60 \mathrm{E}-01$ \\
80 & 12 & $6.52 \mathrm{E}-01$ \\
80 & 24 & $6.81 \mathrm{E}-01$ \\
80 & 24 & $7.34 \mathrm{E}-01$ \\
\hline
\end{tabular}


Technetium-99 Analytical Results from the Resin Leach Test Experiment

\begin{tabular}{cc}
\hline $\begin{array}{c}\text { Time Elapsed } \\
\text { (hours) }\end{array}$ & ${ }^{99}$ Tc $(\mu \mathrm{g} / \mathrm{L})$ \\
\hline 2 & $1.85 \mathrm{E}-01$ \\
2 & $1.59 \mathrm{E}-01$ \\
6 & $1.06 \mathrm{E}-01$ \\
6 & $9.48 \mathrm{E}-02$ \\
24 & $7.93 \mathrm{E}-02$ \\
24 & $6.38 \mathrm{E}-02$ \\
48 & $6.30 \mathrm{E}-02$ \\
48 & $4.85 \mathrm{E}-02$ \\
72 & $4.68 \mathrm{E}-02$ \\
72 & $4.99 \mathrm{E}-02$ \\
96 & $5.38 \mathrm{E}-02$ \\
96 & $3.79 \mathrm{E}-02$ \\
\hline
\end{tabular}

Technetium-99 Analytical Results from the Method 1315 Experiment

\begin{tabular}{cc}
\hline $\begin{array}{c}\text { Cumulative } \\
\text { Time (days) }\end{array}$ & ${ }^{99} \mathrm{Tc}(\mu \mathrm{g} / \mathrm{L})$ \\
\hline 0.08 & $<2.05 \mathrm{E}-02$ \\
1 & $<2.05 \mathrm{E}-02$ \\
2 & $<2.05 \mathrm{E}-02$ \\
8 & $<2.05 \mathrm{E}-02$ \\
14 & $<2.05 \mathrm{E}-02$ \\
\hline
\end{tabular}




\section{Appendix B}

Results Obtained from Previous Analysis Conducted by WSCF Laboratory on the Resin.

Data Provide to PNNL by CHPRC

\begin{tabular}{|c|c|c|c|c|}
\hline \multirow{2}{*}{$\begin{array}{l}\text { Sample Numbers } \\
\text { WSCF20091238 } \\
\text { Constituent } \\
\end{array}$} & \multirow[b]{2}{*}{ Units } & \multicolumn{2}{|c|}{$\begin{array}{c}\text { B234V2 \& B1YCB6 } \\
\text { W15-765 New }\end{array}$} & \multirow{2}{*}{$\begin{array}{c}\text { Resin } \\
\text { Maximum } \\
\text { MDL** } \\
\end{array}$} \\
\hline & & Result & RQ & \\
\hline \multicolumn{5}{|l|}{ Anions } \\
\hline Fluoride & $\mathrm{mg} / \mathrm{kg}$ & $<1.49$ & DU & 1.5 \\
\hline Chloride & $\mathrm{mg} / \mathrm{kg}$ & 36.4 & $\mathrm{D}$ & 2.1 \\
\hline Nitrogen in Nitrate & $\mathrm{mg} / \mathrm{kg}$ & 45.7 & $\mathrm{D}$ & 1.5 \\
\hline Phosphate by ion chromatography (IC) & $\mathrm{mg} / \mathrm{kg}$ & $<3.47$ & DU & 3.5 \\
\hline Sulfate & $\mathrm{mg} / \mathrm{kg}$ & $<3.27$ & DU & 3.3 \\
\hline Cyanide & $\mathrm{mg} / \mathrm{kg}$ & 3,060 & & 0.2 \\
\hline Hexavalent Chromium & $\mathrm{mg} / \mathrm{kg}$ & 0.3 & & 0.1 \\
\hline \multicolumn{5}{|l|}{ Metals } \\
\hline Antimony & $\mathrm{mg} / \mathrm{kg}$ & $<0.298$ & $\mathrm{U}$ & 0.312 \\
\hline Arsenic & $\mathrm{mg} / \mathrm{kg}$ & $<0.398$ & $\mathrm{U}$ & 0.416 \\
\hline Barium & $\mathrm{mg} / \mathrm{kg}$ & $<0.199$ & $\mathrm{U}$ & 0.208 \\
\hline Beryllium & $\mathrm{mg} / \mathrm{kg}$ & $<0.399$ & $\mathrm{U}$ & 0.399 \\
\hline Beryllium & $\mathrm{mg} / \mathrm{kg}$ & $<0.0498$ & $\mathrm{U}$ & 0.052 \\
\hline Cadmium & $\mathrm{mg} / \mathrm{kg}$ & $<0.0995$ & $\mathrm{U}$ & 0.104 \\
\hline Chromium & $\mathrm{mg} / \mathrm{kg}$ & 9.56 & & 0.52 \\
\hline Lead & $\mathrm{mg} / \mathrm{kg}$ & 0.2 & & 0.104 \\
\hline Mercury & $\mathrm{mg} / \mathrm{kg}$ & $<0.0498$ & $\mathrm{U}$ & 0.052 \\
\hline Nickel & $\mathrm{mg} / \mathrm{kg}$ & 0.31 & & 0.208 \\
\hline Nitrogen in Ammonium & $\mathrm{mg} / \mathrm{kg}$ & 12.1 & & 8.47 \\
\hline Selenium & $\mathrm{mg} / \mathrm{kg}$ & $<0.298$ & $\mathrm{U}$ & 0.312 \\
\hline Silver & $\mathrm{mg} / \mathrm{kg}$ & 0.42 & & 0.104 \\
\hline Thallium & $\mathrm{mg} / \mathrm{kg}$ & $<0.0995$ & $\mathrm{U}$ & 0.104 \\
\hline Uranium & $\mathrm{mg} / \mathrm{kg}$ & 0.24 & & 0.052 \\
\hline Vanadium & $\mathrm{mg} / \mathrm{kg}$ & 0.74 & & 0.208 \\
\hline Zinc & $\mathrm{mg} / \mathrm{kg}$ & $<0.796$ & $\mathrm{U}$ & 0.833 \\
\hline \multicolumn{5}{|l|}{ Volatiles } \\
\hline 1,1,1-Trichloroethane & $\mu \mathrm{g} / \mathrm{kg}$ & $<5.0$ & $\mathrm{U}$ & 5 \\
\hline 1,1,2,2-Tetrachloroethane & $\mu \mathrm{g} / \mathrm{kg}$ & $<5.0$ & $\mathrm{U}$ & 5 \\
\hline 1,1,2-Trichloroethane & $\mu \mathrm{g} / \mathrm{kg}$ & $<5.0$ & $\mathrm{U}$ & 5 \\
\hline 1,1-Dichloroethane & $\mu \mathrm{g} / \mathrm{kg}$ & $<5.0$ & $\mathrm{U}$ & 5 \\
\hline 1,1-Dichloroethene & $\mu \mathrm{g} / \mathrm{kg}$ & $<5.0$ & $\mathrm{U}$ & 5 \\
\hline 1,2-Dichloroethane & $\mu \mathrm{g} / \mathrm{kg}$ & $<5.0$ & $\mathrm{U}$ & 5 \\
\hline 1,2-Dichloroethene & $\mu \mathrm{g} / \mathrm{kg}$ & $<5.0$ & $\mathrm{U}$ & 5 \\
\hline
\end{tabular}

B.1 
Results Obtained from Previous Analysis Conducted by WSCF Laboratory on the Resin. Data Provide to PNNL by CHPRC

\begin{tabular}{|c|c|c|c|c|}
\hline \multirow{2}{*}{$\begin{array}{l}\text { Sample Numbers } \\
\text { WSCF20091238 } \\
\text { Constituent }\end{array}$} & \multirow[b]{2}{*}{ Units } & \multicolumn{2}{|c|}{$\begin{array}{c}\text { B234V2 \& B1YCB6 } \\
\text { W15-765 New }\end{array}$} & \multirow{2}{*}{$\begin{array}{c}\text { Resin } \\
\text { Maximum } \\
\text { MDL** } \\
\end{array}$} \\
\hline & & Result & RQ & \\
\hline 1,2-Dichloropropane & $\mu \mathrm{g} / \mathrm{kg}$ & $<5.0$ & $\mathrm{U}$ & 5 \\
\hline 1-Butanol & $\mu \mathrm{g} / \mathrm{kg}$ & $<500$ & $\mathrm{U}$ & 500 \\
\hline 2-Butanone & $\mu \mathrm{g} / \mathrm{kg}$ & $<5.0$ & $\mathrm{U}$ & 5 \\
\hline 2-Hexanone & $\mu \mathrm{g} / \mathrm{kg}$ & $<5.0$ & $\mathrm{U}$ & 5 \\
\hline Acetone & $\mu \mathrm{g} / \mathrm{kg}$ & $<5.0$ & $\mathrm{U}$ & 5 \\
\hline Acetonitrile & $\mu \mathrm{g} / \mathrm{kg}$ & $<9.90$ & $\mathrm{U}$ & 10 \\
\hline Benzene & $\mu \mathrm{g} / \mathrm{kg}$ & $<5.0$ & $\mathrm{U}$ & 5 \\
\hline Bromodichloromethane & $\mu \mathrm{g} / \mathrm{kg}$ & $<5.0$ & $\mathrm{U}$ & 5 \\
\hline Bromoform & $\mu \mathrm{g} / \mathrm{kg}$ & $<5.0$ & $\mathrm{U}$ & 5 \\
\hline Bromomethane & $\mu \mathrm{g} / \mathrm{kg}$ & $<5.0$ & $\mathrm{U}$ & 5 \\
\hline Carbon disulfide & $\mu \mathrm{g} / \mathrm{kg}$ & $<5.0$ & $\mathrm{U}$ & 5 \\
\hline Carbon tetrachloride & $\mu \mathrm{g} / \mathrm{kg}$ & 25,000 & & 5 \\
\hline Chlorobenzene & $\mu \mathrm{g} / \mathrm{kg}$ & $<5.0$ & $\mathrm{U}$ & 5 \\
\hline Chloroethane & $\mu \mathrm{g} / \mathrm{kg}$ & $<5.0$ & $\mathrm{U}$ & 5 \\
\hline Chloroform & $\mu \mathrm{g} / \mathrm{kg}$ & 1,800 & & 5 \\
\hline Chloromethane & $\mu \mathrm{g} / \mathrm{kg}$ & $<5.0$ & $\mathrm{U}$ & 5 \\
\hline cis-1,3-Dichloropropane & $\mu \mathrm{g} / \mathrm{kg}$ & $<5.0$ & $\mathrm{U}$ & 5 \\
\hline Ethylbenzene & $\mu \mathrm{g} / \mathrm{kg}$ & $<5.0$ & $\mathrm{U}$ & 5 \\
\hline Methylene chloride & $\mu \mathrm{g} / \mathrm{kg}$ & $<5.0$ & $\mathrm{U}$ & 5 \\
\hline Styrene & $\mu \mathrm{g} / \mathrm{kg}$ & $<5.0$ & $\mathrm{U}$ & 5 \\
\hline Tetrachloroethene & $\mu \mathrm{g} / \mathrm{kg}$ & $<5.0$ & $\mathrm{U}$ & 5 \\
\hline Toluene & $\mu \mathrm{g} / \mathrm{kg}$ & $<5.0$ & $\mathrm{U}$ & 5 \\
\hline trans-1,3-Dichloropropane & $\mu \mathrm{g} / \mathrm{kg}$ & $<5.0$ & $\mathrm{U}$ & 5 \\
\hline Trichloroethene & $\mu \mathrm{g} / \mathrm{kg}$ & 140 & & 1 \\
\hline Vinyl Chloride & $\mu \mathrm{g} / \mathrm{kg}$ & $<5.0^{*}$ & $\mathrm{U}$ & 5 \\
\hline Xylenes (total) & $\mu \mathrm{g} / \mathrm{kg}$ & $<5.0$ & $\mathrm{U}$ & 5 \\
\hline $\begin{array}{l}\text { Semi-Volatiles } \\
\text { 1,2,4-Trichlorobenzene }\end{array}$ & $\mu \mathrm{g} / \mathrm{L}$ & & & 100 \\
\hline 1,4-Dichlorobenzene & $\mu \mathrm{g} / \mathrm{L}$ & $<80.0$ & $\mathrm{U}$ & 80 \\
\hline 2,4-Dinitrotoluene & $\mu \mathrm{g} / \mathrm{L}$ & & & 25 \\
\hline 2-Chlorophenol & $\mu \mathrm{g} / \mathrm{L}$ & & & 25 \\
\hline 2-methylphenol (cresol, o-) & $\mu \mathrm{g} / \mathrm{L}$ & $<25.0$ & $\mathrm{U}$ & 25 \\
\hline 3 \& 4 Methylphenol Total & $\mu \mathrm{g} / \mathrm{L}$ & $<25.0$ & $\mathrm{U}$ & 25 \\
\hline 4-Chloro-3-methylphenol & $\mu \mathrm{g} / \mathrm{L}$ & & & 25 \\
\hline 4-Nitrophenol & $\mu \mathrm{g} / \mathrm{L}$ & & & 150 \\
\hline Acenaphthene & $\mu \mathrm{g} / \mathrm{L}$ & & & 140 \\
\hline Dibenz[a]anthracene & $\mu \mathrm{g} / \mathrm{L}$ & $<25.0$ & $\mathrm{U}$ & 25 \\
\hline
\end{tabular}


Results Obtained from Previous Analysis Conducted by WSCF Laboratory on the Resin. Data Provide to PNNL by CHPRC

\begin{tabular}{|c|c|c|c|c|}
\hline \multirow{2}{*}{$\begin{array}{l}\text { Sample Numbers } \\
\text { WSCF20091238 } \\
\text { Constituent }\end{array}$} & \multirow[b]{2}{*}{ Units } & \multicolumn{2}{|c|}{$\begin{array}{c}\text { B234V2 \& B1YCB6 } \\
\text { W15-765 New }\end{array}$} & \multirow{2}{*}{$\begin{array}{c}\text { Resin } \\
\text { Maximum } \\
\text { MDL** } \\
\end{array}$} \\
\hline & & Result & $\mathbf{R Q}$ & \\
\hline Diethylphthalate & $\mu \mathrm{g} / \mathrm{L}$ & $<100$ & $\mathrm{U}$ & 100 \\
\hline Dimethyl phthalate & $\mu \mathrm{g} / \mathrm{L}$ & $<25.0$ & $\mathrm{U}$ & 25 \\
\hline Di-n-butylphthalate & $\mu \mathrm{g} / \mathrm{L}$ & $<120$ & $\mathrm{U}$ & 120 \\
\hline Kerosene & $\mu \mathrm{g} / \mathrm{L}$ & $<6,200$ & $\mathrm{U}$ & 6,200 \\
\hline N-Nitrosodi-n-dipropylamine & $\mu \mathrm{g} / \mathrm{L}$ & & & 30 \\
\hline Pentachlorophenol & $\mu \mathrm{g} / \mathrm{L}$ & & & 50 \\
\hline Phenol & $\mu \mathrm{g} / \mathrm{L}$ & $<25.0$ & $\mathrm{U}$ & 25 \\
\hline Pyrene & $\mu \mathrm{g} / \mathrm{L}$ & & & 25 \\
\hline Total Pet HC & $\mu \mathrm{g} / \mathrm{L}$ & $<6,200$ & $\mathrm{U}$ & 6,200 \\
\hline Radionuclides & & & & \\
\hline Ac-228 & $\mathrm{pCi} / \mathrm{g}$ & $<57$ & $\mathrm{U}$ & 57 \\
\hline Am-241 & $\mathrm{pCi} / \mathrm{g}$ & $<0.30$ & $\mathrm{U}$ & 0.31 \\
\hline Am-241 & $\mathrm{pCi} / \mathrm{g}$ & $<47$ & $\mathrm{U}$ & 54 \\
\hline Am-243 tracer by AEA & $\mathrm{pCi} / \mathrm{g}$ & 20 & & 0.18 \\
\hline Ba-133 by GEA & $\mathrm{pCi} / \mathrm{g}$ & $<11$ & $\mathrm{U}$ & 11 \\
\hline Be-7 by GEA & $\mathrm{pCi} / \mathrm{g}$ & $<1$ & U & 1 \\
\hline $\mathrm{Bi}-212$ & $\mathrm{pCi} / \mathrm{g}$ & $<95$ & $\mathrm{U}$ & 95 \\
\hline $\mathrm{Bi}-214$ & $\mathrm{pCi} / \mathrm{g}$ & $<26$ & $\mathrm{U}$ & 26 \\
\hline C-14 & $\mathrm{pCi} / \mathrm{g}$ & 600 & & 43.6 \\
\hline Ce-144 & $\mathrm{pCi} / \mathrm{g}$ & $<45$ & $\mathrm{U}$ & 45 \\
\hline Cerium/Praseodymium-144 & $\mathrm{pCi} / \mathrm{g}$ & $<90$ & U & 90 \\
\hline Сo-60 & $\mathrm{pCi} / \mathrm{g}$ & 475 & & 0.7 \\
\hline Co-60 & $\mathrm{pCi} / \mathrm{g}$ & 422 & & 12 \\
\hline Cs-134 & $\mathrm{pCi} / \mathrm{g}$ & $<13$ & U & 13 \\
\hline Cs-137 & $\mathrm{pCi} / \mathrm{g}$ & $<1.1$ & U & 1.1 \\
\hline Cs-137 & $\mathrm{pCi} / \mathrm{g}$ & $<12$ & $\mathrm{U}$ & 12 \\
\hline Eu-152 & $\mathrm{pCi} / \mathrm{g}$ & $<22$ & $\mathrm{U}$ & 22 \\
\hline Eu-154 & $\mathrm{pCi} / \mathrm{g}$ & $<33$ & $\mathrm{U}$ & 35 \\
\hline Eu-155 & $\mathrm{pCi} / \mathrm{g}$ & $<24$ & U & 24 \\
\hline Gross Alpha & $\mathrm{pCi} / \mathrm{g}$ & 4.8 & & 2.1 \\
\hline Gross Beta & $\mathrm{pCi} / \mathrm{g}$ & 17,200 & & 2.8 \\
\hline H3 & $\mathrm{pCi} / \mathrm{g}$ & 100 & & 65.7 \\
\hline I-129 & $\mathrm{pCi} / \mathrm{g}$ & $<1.57$ & U & 1.57 \\
\hline K-40 & $\mathrm{pCi} / \mathrm{g}$ & $<200$ & $\mathrm{U}$ & 200 \\
\hline Nb-94 & $\mathrm{pCi} / \mathrm{g}$ & $<10$ & $\mathrm{U}$ & 10 \\
\hline $\mathrm{Ni}-63$ & $\mathrm{pCi} / \mathrm{g}$ & $<150$ & $\mathrm{U}$ & 161 \\
\hline Np-237 & pCi/g & $<5.01$ & U & 18.6 \\
\hline
\end{tabular}


Results Obtained from Previous Analysis Conducted by WSCF Laboratory on the Resin. Data Provide to PNNL by CHPRC

\begin{tabular}{|c|c|c|c|c|}
\hline \multirow{2}{*}{$\begin{array}{l}\text { Sample Numbers } \\
\text { WSCF20091238 } \\
\text { Constituent } \\
\end{array}$} & \multirow[b]{2}{*}{ Units } & \multicolumn{2}{|c|}{$\begin{array}{c}\text { B234V2 \& B1YCB6 } \\
\text { W15-765 New }\end{array}$} & \multirow{2}{*}{$\begin{array}{c}\text { Resin } \\
\text { Maximum } \\
\text { MDL** }\end{array}$} \\
\hline & & Result & $\mathbf{R Q}$ & \\
\hline Pa-231 & $\mathrm{pCi} / \mathrm{g}$ & $<0.100$ & $\mathrm{U}$ & 0.13 \\
\hline $\mathrm{Pb}-212$ & $\mathrm{pCi} / \mathrm{g}$ & $<14$ & $\mathrm{U}$ & 14 \\
\hline $\mathrm{Pb}-214$ & $\mathrm{pCi} / \mathrm{g}$ & 26.9 & & 16 \\
\hline Pu-238 & $\mathrm{pCi} / \mathrm{g}$ & $<0.32$ & $\mathrm{U}$ & 0.32 \\
\hline Pu-239/240 by AEA & $\mathrm{pCi} / \mathrm{g}$ & $<0.085$ & & 0.096 \\
\hline Pu-242 & $\mathrm{pCi} / \mathrm{g}$ & 30 & & 0.098 \\
\hline Ra-226 & $\mathrm{pCi} / \mathrm{g}$ & $<26$ & $\mathrm{U}$ & 26 \\
\hline Ra-228 & $\mathrm{pCi} / \mathrm{g}$ & $<57$ & $\mathrm{U}$ & 57 \\
\hline Ru-103 & $\mathrm{pCi} / \mathrm{g}$ & $<9.6$ & $\mathrm{U}$ & 9.6 \\
\hline Ru-106 & $\mathrm{pCi} / \mathrm{g}$ & $<91$ & $\mathrm{U}$ & 91 \\
\hline Sb-125 & $\mathrm{pCi} / \mathrm{g}$ & $<2.6$ & $\mathrm{U}$ & 2.6 \\
\hline Sb-125 & $\mathrm{pCi} / \mathrm{g}$ & $<24$ & $\mathrm{U}$ & 24 \\
\hline Se-79 & $\mathrm{pCi} / \mathrm{g}$ & 355 & & 146 \\
\hline Sn-113 & $\mathrm{pCi} / \mathrm{g}$ & $<10$ & $\mathrm{U}$ & 10 \\
\hline Sr-85 Tracer by Beta Counting & $\%$ & 94.7 & & 0 \\
\hline Sr-89/90 & $\mathrm{pCi} / \mathrm{g}$ & $<84$ & $\mathrm{U}$ & 100 \\
\hline Tc-99 & $\mathrm{pCi} / \mathrm{g}$ & 208,000 & & 9.96 \\
\hline Th-234 & $\mathrm{pCi} / \mathrm{g}$ & $<420$ & $\mathrm{U}$ & 440 \\
\hline Tin-126 & $\mathrm{pCi} / \mathrm{g}$ & $<18$ & $\mathrm{U}$ & 18 \\
\hline Tl-208 & $\mathrm{pCi} / \mathrm{g}$ & $<11$ & $\mathrm{U}$ & 11 \\
\hline U-232 Tracer by AEA & $\mathrm{pCi} / \mathrm{g}$ & 20 & & 0.17 \\
\hline $\mathrm{U}-233 / 234$ & $\mathrm{pCi} / \mathrm{g}$ & 0.16 & & 0.08 \\
\hline $\mathrm{U}-235$ & $\mathrm{pCi} / \mathrm{g}$ & $<0.087$ & $\mathrm{U}$ & 0.095 \\
\hline U-235 & $\mathrm{pCi} / \mathrm{g}$ & $<42$ & $\mathrm{U}$ & 43 \\
\hline $\mathrm{U}-238$ & $\mathrm{pCi} / \mathrm{g}$ & $<0.080$ & $\mathrm{U}$ & 0.08 \\
\hline Zn-65 & $\mathrm{pCi} / \mathrm{g}$ & $<36$ & $\mathrm{U}$ & 36 \\
\hline
\end{tabular}




\section{Dis tribution}

No of

Copies

\section{EXTERNAL}

2 DOE - Richland Operations

John Morse (2)

4 CH2M Hill Plateau Remediation Contractor Sally Simmons (2)

Mark Byrnes (2)

R3-60

R3-60
No. of

Copies

INTERNAL

$4 \quad$ Pacific Northwest National Laboratory

KE Parker

K3-62

E. M. Pierce

K3-62

MM Valenta (2)

P7-54

Distr. 1 



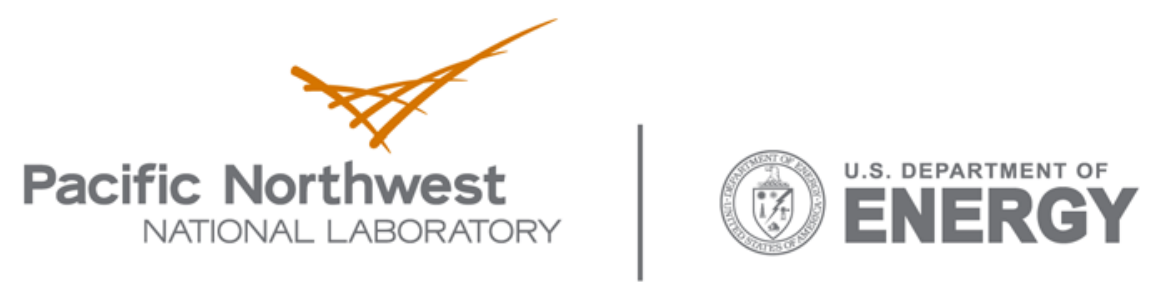

902 Battelle Boulevard

P.O. Box 999

Richland, WA 99352

1-888-375-PNNL (7665)

www.pnl.gov 